\title{
France and the Failure to Modernize Macroeconomic Institutions
}

The Legacy of Western European Fiscal and Monetary Institutions For the New World:

The Seventeenth to the Nineteenth Century

\author{
$12^{\text {th }}$ International Economic History Congress \\ Madrid \\ Spain
}

August 25, 1998

Corrected Version January 1999

Eugene N. White

Rutgers University and NBER

Department of Economics

Rutgers University

New Brunswick NJ 08901-1251

USA

white@economics.rutgers.edu 
By the beginning of the eighteenth century, France had laid claim to a great colonial empire in the Americas. Following French explorers in the sixteenth century, colonies were founded in the seventeenth century. Quebec was settled in 1608, St. Kitts in 1627 and Martinique and Guadaloupe in 1635. Spurred by sugar production in the West Indies and the beaver trade in Quebec, French America expanded. Yet, this empire was quickly lost. After the War of the Spanish Succession (1713), Acadia (Nova Scotia), Newfoundland, and Hudson's Bay were ceded to Great Britain. Defeat in the Seven Years War in 1763 deprived France of all lands in North America and some of its West Indian Islands (Butel and Crouzet, 1998). While military failures were centrally important for this loss, France's flawed macroeconomic institutions and policies hindered her ability to protect and develop her colonies. This paper examines the origins and operation of the French ancien régime's fiscal and monetary institutions. The weakness of these institutions contributed not only to France's difficulties in projecting her power overseas but also to the crisis and ultimately the collapse of the monarchy.

\section{The Theory of Optimal Macroeconomic Policy}

The grand ambitions of the French Crown were held in check by its inability to conduct a more efficient macroeconomic policy that would raise the needed revenue while minimizing economic distortions. Theories of optimal macroeconomic policy and sovereign debt offer some insights into the weaknesses of French policy and what reforms were necessary.

In the simplest setting (Barro, 1987 and 1989; Mankiw, 1987), optimal monetary and fiscal policy requires that the government satisfy a present value budget constraint where the outstanding current real government debt equals the sum of all present and future real tax revenues less all present and future real government expenditures. This may be re-stated as the existing debt must be fully funded by cumulative budget surpluses. In the absence of tax collection costs, the government would set a constant tax on output (an income or sales tax) to satisfy this constraint. Substantial increases in spending, such as wartime expenditures, would be financed by debt, funded by peacetime surpluses. This "tax smoothing policy avoids intertemporal distortions and minimizes the intratemporal policy-induced distortions. The presence of collection costs (Bordo and Vègh, 1998) adds a new distortion that makes the use of seigniorage (the tax on real money balances) part of the next best policy. The government now has two policy instruments---the tax rate and the inflation rate--that cause deadweight social losses; and the government must chose the tax rate and the inflation rate to minimize the present value of these social losses subject to the budget constraint. The optimal policy here consists of fixed tax and inflation rates for "tax smoothing" and "inflation smoothing," where the marginal social cost of taxation and seigniorage are equal. The mix of taxation and inflation may change if disruptions, most likely civil or foreign wars, raise the cost of tax collections. Higher collection costs increase the distortionary effects of taxation 
and induce the government to switch to a higher inflation rate---a more distortionary policy. Similarly, a less desirable policy will be employed if borrowing is costly, where capital markets are not perfect and risk premia are assessed. A government will respond to this situation by substituting higher taxes and inflation for borrowing.

From the sixteenth to the eighteenth centuries, Western European countries were on a specie standard and were subject to large fiscal shocks in the form of frequent wars. Although the coinage was sometimes debased to generate revenue, seigniorage was usually a modest source of revenue for the French Crown, as suggested by the theory of optimal macroeconomic policy. Adherence to a specie standard may also have been a commitment mechanism that allowed a government to follow a time consistent policy, where in the absence of inflation debt retained its real value (Bordo and Kydland, 1995). Without such a commitment to price stability, it would be difficult for a government to use debt finance. Ceding control of the inflation rate, the French Crown gained some limited seigniorage and was left with the tax rate as the major policy instrument.

The ability of a government to issue debt is central to tax smoothing. While expenditures and tax revenues might be reasonably predictable during peacetime, the uncertain duration and intensity of wars make wartime expenditures extremely variable. To ensure tax smoothing, the government will incur debt when faced with an unexpectedly large increase in spending and adjust the tax rate to fund the debt over a long period. In the period examined in this paper, the rising cost of warfare required major fiscal innovations for major powers with colonial ambitions. Examining eighteenth century Great Britain and France, Barro (1987), Bordo and White $(1991,1994)$ found that Britain came closest to following an optimal fiscal policy. Taxes were smoothed, rising not just for the duration of the war but during and after the war, and wartime budget deficits induced increases in interest rates that brought about needed short-term adjustments in consumption and investment.

The French Crown's policies appear to have been inferior, with greater use of seigniorage and higher borrowing costs, thus constraining its ability to finance war. Special interests obstructed many reforms essential to improving the efficiency of fiscal policy. In spite of attempts to reform the tax structure and produce a unified national system, rates varied considerably by regional and personal legal status, producing large economic distortions. Linked to the tax structure was the tax collection system, which produced lower revenues, reflecting the Crown's difficulty in monitoring tax collectors and its own risk aversion. Central to France's fiscal problems was the absence of national institutions representing taxpayers that could legitimize tax increases and reforms. Instead judicial officials checked the Crown's efforts. In contradiction of the tax smoothing tenets of optimal policy, the officials insisted that there could be no permanent increase in taxes and taxes could only rise for the duration of any war.

The ability to borrow in peak times of spending was essential to the conduct of an efficient macroeconomic policy. Higher than expected expenditures not matched by tax increases violate the present value constraint. Unable to cut 
expenditures or raise revenue, a government may default to reduce its servicing of the debt, thereby satisfying the constraint. But, the prospect of default will drive away potential lenders unless there is an enforcement mechanism to induce repayment. The problem for sovereign debt is that there is no internal legal or external enforcement device; only the desire for continued access to loans induces a government to service its debts. ${ }^{1}$ To maintain its reputation the government must service its debts to fulfill the lenders' expectations. However well-intentioned, a government may still find it impossible to repay the debt in full if huge wars unexpectedly drive up expenditures and taxes cannot be raised sufficiently. This possibility might deter lenders unless they consider sovereign debt as a contingent claim. This type of financial instrument allows some partial shifting of risk to the lender in the case of excusable defaults, defaults where lenders understand that there are potential bad outcomes (Grossman and Van Huyck, 1988). This arrangement gains the government some insurance against disaster, shifting risk in the form of partial defaults and permitting borrowing soon afterwards. Unjustifiable debt repudiation, including a complete abandonment of the debt, would not allow a quick return to the markets. ${ }^{2}$ The French Crown borrowed under these conditions, but its frequent defaults imposed a substantial risk premium that raised the costs of financing deficits.

These many deviations from optimal macroeconomic policy reduced France's revenue, hindering the greatest power on the European continent from acting as a truly great colonial power in the Americas. The magnitude of the revenue problem may be seen in a comparison of France and Britain in the eighteenth century.

\section{The Fiscal Demands of a Great Power}

As a great power seeking to project its influence and plant colonies in the New World, France needed to generate revenue. But, its fiscal system had a limited capacity to grow. Table 1 illustrates France's revenue generation problem vis-à-vis Great Britain, her chief eighteenth century rival. France was by far the larger power measured by population and national income at the beginning and end of the century. Yet, even considering the fact that her subjects had lower per capita incomes, what is striking is that the French fisc produced proportionally less revenue central government revenue than her smaller rival. And, this disparity grew over time. In 1715, France's population was triple Britain's and her national income was less than triple, yet tax revenues were only double. Taxes and taxes per capita were a smaller fraction of GNP. By 1788, Britain's population had grown a little faster and her national income was nearly half that of France's, widening the gap in per capita incomes. Total British tax revenue

\footnotetext{
${ }^{1}$ Models where deterrents and external enforcement mechanisms exist (Bulow and Rogoff, 1989 and 1989) are not appropriate here.

2 Efficient risk shifting may be hindered if the sovereign has a high probability of losing power, a high rate of time preference, or low risk aversion.
} 
now nearly approximated total French taxes. France had increased her per capita taxes slightly, while British subjects bore more than double the rate their cross channel contemporaries paid. Westminster may have raised taxes; but the share of taxes to GNP was unchanged, thus milking the growing economy, Versailles failed to do so and saw taxes to GNP slip from 9.4 to 6.8 percent.

\section{Table 1}

\section{French and British Income and Taxation}

\begin{tabular}{l|cccc}
\hline & France & Britain & France & Britain \\
\hline Year & $\mathbf{1 7 1 5}$ & $\mathbf{1 7 1 5}$ & $\mathbf{1 7 8 8}$ & $\mathbf{1 7 8 8}$ \\
Population & $19,250,000$ & $7,129,000$ & $26,596,000$ & $9,369,000$ \\
$\begin{array}{l}\text { Nominal GNP, livres/pounds millions } \\
\text { (millions of pounds sterling) }\end{array}$ & 1,760 & 46.2 & 6,977 & 134.8 \\
GNP per capita & $(116)$ & & $(280.8)$ & \\
& 91.4 & 6.5 & 262.3 & 14.4 \\
Tax Revenue, livres/pounds millions & $(6.0)$ & & $(10.6)$ & \\
(millions of pounds sterling) & 166.0 & 5.8 & 472.4 & 16.8 \\
Taxes to GNP percent & $(11.0)$ & & $(19.0)$ & \\
Taxes per capita, livres/pounds & 9.4 & 12.5 & 6.8 & 12.4 \\
(pounds sterling) & 8.6 & 0.8 & 17.8 & 1.8 \\
\hline
\end{tabular}

Note: All GNP figures are nominal. The figures for 1788 were obtained from Weir (1989). For 1715, Mathias and O'Brien (1976) provide most statistics. Their figures for commodity output are raised by 20 and 32 percent to account for rest of GNP in the French and British economies (Lévy-Leboyer and Bourguignon, 1985 Table A-1, and Mathias and O'Brien, 1976 p. 608). Livres tournois are converted into pounds sterling at prevailing exchange rates (McCusker, 1978 and Bouchary, 1937).

Mathias and O'Brien (1976) looked at this problem in real terms over time and found that the pattern held in spite of economic fluctuations and the demands of war. Table 2 shows that over the course of the eighteenth century, the burden of taxation did not increase in real terms in France. Considering either 1715 or 1725 as a base year, tax revenues in current livres more than doubled by 1785 . In constant livres, there was a much smaller increase, perhaps 50 percent, once war years are isolated. However, the real per capita level of taxation was nearly constant. It rose in wartime but declined afterwards to approximately the same level. A similar result was obtained by Riley (1987), using slightly different data. ${ }^{3}$ In contrast, nominal British tax revenues more than doubled but total real revenues almost doubled. There is also a modest rise in the real per capita level of British taxation. For the Netherlands, Fritschy (1990) found that in Holland and in the smaller, poorer province of Overijssel, nominal tax revenues changed little, although price declines propped up their real value in the middle of the century. Contrary to the experience of Britain and France,

\footnotetext{
${ }^{3}$ Riley's data are extended to cover 1775-1785, using tax revenues from White (1989) and Labrousse's index (1970), Vol. II, p. 387. Hoffman $(1986,1995)$ shows a similar pattern in real total and per capita taxes measured in grain equivalents.
} 
Dutch per capita tax revenue declined, reflecting low economic growth and efforts, until 1780, to keep out of war.

While acknowledging the fragility of their data and the absence of data on services that bulked larger in the British economy, Mathias and O'Brien also compared taxes as a share of commodity output. They found that French tax revenues as a share of commodity output scarcely changed over the course of the century, as seen in Table 3, hovering above 10 percent. In Britain, taxes commanded a higher share of output beginning at 16 to 18 percent and rising to 18 to 22 percent. Thus, taxes rose faster than the economy grew in Britain. This comparison adds to the evidence that France was not mobilizing sufficient resources in its political and military struggle in Europe and overseas.

Table 2

The Growth of French, British, and Dutch Tax Revenue

\begin{tabular}{|c|c|c|c|c|c|c|c|c|c|c|}
\hline Year & $\begin{array}{c}\text { France } \\
\text { Tax } \\
\text { Revenue } \\
\text { livres } \\
\text { millions }\end{array}$ & $\begin{array}{c}\text { France } \\
\text { Real Tax } \\
\text { Revenue } \\
1715 \\
=100\end{array}$ & $\begin{array}{c}\text { France } \\
\text { Real Tax } \\
\text { Revenue } \\
\text { per } \\
\text { capita } \\
1715 \\
=100\end{array}$ & $\begin{array}{c}\text { France } \\
\text { Real Tax } \\
\text { Revenue } \\
\text { per } \\
\text { capita } \\
1730 \\
=100 \\
\text { (Riley) } \\
\end{array}$ & $\begin{array}{c}\text { Britain } \\
\text { Tax } \\
\text { Revenue } \\
\text { in } \\
\text { pounds } \\
\text { millions }\end{array}$ & $\begin{array}{c}\text { Britain } \\
\text { Real Tax } \\
\text { Revenue } \\
1700 \\
=100\end{array}$ & $\begin{array}{c}\text { Britain } \\
\text { Real Tax } \\
\text { Revenue } \\
\text { per } \\
\text { capita in } \\
\text { pounds } \\
1715 \\
=100 \\
\end{array}$ & $\begin{array}{l}\text { Holland } \\
\text { Tax } \\
\text { Revenue } \\
\text { Guilders } \\
\text { millions }\end{array}$ & $\begin{array}{c}\text { Holland } \\
\text { (Overijssel) } \\
\text { Real Tax } \\
\text { Revenue } \\
1750 \\
=100\end{array}$ & $\begin{array}{c}\text { Holland } \\
\text { (Overijssel) } \\
\text { Real Tax } \\
\text { Revenue per } \\
\text { capita } \\
1750=100\end{array}$ \\
\hline 1715 & 166 & 100 & 100 & & 5.8 & 100 & 100 & & & \\
\hline 1720 & & & & & 6.1 & 110 & 110 & 19.1 & $81(89)$ & 74 (115) \\
\hline 1725 & 198 & 125 & 124 & & 5.9 & 100 & 101 & & & \\
\hline 1730 & 186 & 144 & 130 & 100 & 6.2 & 113 & 113 & 19.5 & $93(120)$ & $87(142)$ \\
\hline $1735^{*}$ & 236 & 174 & 155 & 120 & 5.7 & 108 & 109 & & & \\
\hline $1740 *$ & 201 & 139 & 124 & 113 & 5.9 & 98 & 100 & & (74) & (80) \\
\hline $1745^{*}$ & 245 & 160 & 144 & 137 & 6.6 & 127 & 124 & & & \\
\hline 1750 & 207 & 127 & 114 & 106 & 7.3 & 127 & 122 & 22.0 & $100(100)$ & $100(100)$ \\
\hline 1755 & 253 & 156 & 134 & 117 & 7.2 & 117 & 110 & & & \\
\hline $1760 *$ & & & & 160 & 8.7 & 146 & 132 & 22.6 & $100(103)$ & 100(98) \\
\hline 1765 & 320 & 173 & 138 & 127 & 10.0 & 146 & 128 & & & \\
\hline 1770 & 318 & 137 & 106 & 109 & 10.4 & 149 & 126 & & (73) & (67) \\
\hline 1775 & 362 & 164 & 126 & 101 & 10.7 & 143 & 117 & & & \\
\hline $1780 *$ & 419 & 199 & 145 & 124 & 12.6 & 170 & 135 & & (82) & (76) \\
\hline 1785 & 424 & 183 & 132 & 113 & 14.6 & 190 & 144 & & & \\
\hline
\end{tabular}

Notes: The star $(*)$ denotes a war year. The dates stand for the nearest year to the available budget. The real values are calculated using Mathias and O'Brien's grain index.

Sources: O'Brien and Keyder (1976), Tables 1 and 2, Riley (1987), Tables 3 and 4, White (1989), Tables 1 and 3, Labrousse (1970) Vol. II, p. 387, and Fritschy (1990), Tables 1 and 2.

The question arises why France was unable to generate more revenue and enhance its power in war and overseas. Although it may have been constrained somewhat by its lower income per capita, there is-ignoring for the moment the political economy of taxation-no reason why part of the gap with 
Britain could have been closed. In a simple counterfactual, if France had kept her tax share of GNP at 9.4 percent (well below the 1788 British level of 12.4 percent) instead of letting it fall to 6.8 , government tax revenue would have been 656 million livres instead of 472 million. Such an increase would have been ample funding for war and colonial expansion. Even if the Crown revenues

Table 3

French and British Taxes as a Share of Output (Percent)

\begin{tabular}{c|cc}
\hline Year & $\begin{array}{c}\text { France } \\
\text { Taxes as a } \\
\text { Percentage of } \\
\text { Commodity Output }\end{array}$ & $\begin{array}{c}\text { Britain } \\
\text { Taxes as a } \\
\text { Percentage of } \\
\text { Commodity Output }\end{array}$ \\
\hline 1715 & 11 & 17 \\
1720 & & 17 \\
1725 & 13 & 16 \\
1730 & 15 & 18 \\
$1735^{*}$ & 17 & 18 \\
$1740^{*}$ & 13 & 16 \\
$1745^{*}$ & 15 & 20 \\
1750 & 11 & 18 \\
1755 & 13 & 16 \\
1760 & & 20 \\
1765 & 12 & 19 \\
1770 & 9 & 18 \\
1775 & 10 & 18 \\
$1780^{*}$ & 12 & 21 \\
1785 & 10 & 22 \\
\hline
\end{tabular}

Source: O'Brien and Keyder (1976), Tables 3 and 4.

would have slipped to 8 percent of GNP, taxes would have provided 558 million livres, a figure that would have closed the pre-Revolutionary budget gap of 100 million (White, 1989). Instead of 18 livres, French subjects would have paid 21 livres or 24 livres out of a per capita income of 262 livres. Even at a lower standard of living that the British, this would not seem an intolerable burden. However, French macroeconomic institututions and the political economy of macroeconomic policy had evolved in such a way as to limit even apparently modest changes capable of strengthening the French state.

\section{The Origins and Structure of the French Tax System}

The French fisc had multiple problems. Its key features were determined by the evolution of the French state. Territorial expansion from the middle ages 
onward absorbed new regions that retained separate fiscal regimes, producing a great diversity of taxes and tax rates. Further complicating matters was the ability of regions, groups and individuals to obtain tax exemptions. Over time, this patchwork quilt of taxation produced a sense of general inequity in the tax burden and resistance to the imposition of new taxes or reduction in tax privileges. The ability of the Crown to gain new taxation was hindered by the absence of a national representative institution that could grant new taxes legitimacy. Furthermore, the tax collection system was operated by contractors who had considerable autonomy. The Crown was heavily dependent on these tax collectors to provide short-term funding in anticipation of taxes, although it gradually gained access to the market for long term lending. By linking government finance to the system of tax collection, reform became more difficult. Changes that could have improved efficiency and provided increased revenues proved to be extremely difficult given the complex political economy of French finance. Several times an invigorated Crown initiated new reforms to centralize and simplify the tax system, but in the long run the government had limited success in altering the basic tax structure.

The evolution of the French state shaped the character of the fiscal system. Regular, direct taxation first appeared in Western Europe in the late thirteenth century, when the fiscal pressure of wars forced the Crown to seek resources outside the royal domain and commute service obligations into tax payments. In France, the greater wealth of the royal domain and the absence of an effective central representative institution delayed the imposition of direct taxes (Ormrod, 1995). ${ }^{4} \quad$ In both England and Castile, there were assemblies--the Parliament and the Cortes--representative of the secular nobility, the Church and the towns that met with some regularity and judged the king's requests and grant taxes. The assent of representatives of some taxed subjects conferred legitimacy and acceptance of changes in taxation.

France never developed even modest representative institutions. Composed of delegates from the nobility, clergy and third estate, the Estates General drew up lists of grievances to be presented to the Crown and advised the king on legislation. In the fourteenth century, France had two Estates General, one for the North (Languedoil) and one for the South (Languedoc). By the fifteenth century, there was one body for the whole country, in additional to provincial estates. Although it did not vote on legislation and the monarchy created new taxes without its approval, many French jurists claimed that only the Estates General could vote new taxation (Collins, 1995). Its influence was limited, partly because it met only four times, in 1484, 1560-61, 1588, and 1614-15. The inability of the three Estates General to agree on the reform of the government in 1615 led to its dissolution and abdication of authority to the king (Mousnier, 1980). Vanishing from the scene until 1789, the vacuum was filled by the Parlement de Paris and the regional parlements, composed of privileged noble judges who managed the judicial affairs of the Crown (Doyle, 1974). The pre-

\footnotetext{
${ }^{4}$ Conditioned by their support of the Crown for crusades, the clergy paid regular taxes in England, France, and Spain, negotiated by their representative institutions, judging the king's requests.
} 
eminent Parlement de Paris had authority over central France. By tradition, it legalized all royal acts of taxation or loans by recording them in its registers in formal plenary sessions (Stone, 1981). The ceremony of enregistrement was required to legitimize a monarch's edicts, making them enforceable at law throughout the kingdom. Simultaneously, the enregistrements confirmed the legality of the Crown. If the parlement decided that an edict was illegal or harmful to the kingdom, it read a remonstrance to the king and refused to register it, making the edict legally unenforceable. However, a monarch could force registration by calling a special parliamentary session, a lit de justice. If the parlementaires still proved recalcitrant, the Crown sometimes closed parlement or exiled its members. Flexibility in fiscal policy was limited by the theory most parlementaires held that no new permanent taxes could be decreed, except by the nation as a whole as represented by the Estates-General (Stone, 1981).

When it expanded its authority to new territories, the French Crown often confirmed traditional liberties and granted privileges to new provinces, produced a great variation in taxation, with provincial authorities often retaining power to determine the form of the taxes. The original core of the kingdom, represented by the Estates General of Languedoil had relatively uniform taxation, but the provinces added later, such as Brittany, Burgundy, Dauphiné, and Province, and many enclaves retained relatively autonomous systems. Particularism remained a central feature of the tax system and many other aspects of the French state (Collins, 1988). France stood in strong contrast to England, a smaller realm, but one where there was one Parliament that met frequently, taxes were universal and royal courts handled almost all important cases.

Permanent taxation by the central state began in France only when the state was threatened by capture of the king, John II, in the battle of Poitiers and by the bands of demobilized soldiers after peace with the English in 1360. To raise money, a package of two aides--a 5 percent sales tax and one-thirteenth tax on wholesale wine--and the gabelle a 25 percent salt tax were instituted. Together with the hearth taxes (fouages), which commuted military service for commoners, they formed the core of Crown taxes (Collins, 1988).

Out of the hearth tax, the taille was established, which became the principal direct tax levied by the Crown. The taille was a geographically apportioned fixed sum tax. It was assessed on landed income and took two forms. In northern France, payment of the taille personnelle depended on personal status. Nobles and some bourgeois of privileged towns were exempt from the taille. ${ }^{5}$ Exemption from the taille reélle of southern France depended on whether the status of the land was noble. Originally, the nobles had not been exempt; but Charles VI, a weak king, granted them exemptions from the taille and the aides for production on their properties in 1388. Gradually tax privileges spread to magistrates, royal officers and the leading bourgeois, leaving a heavier tax burden on the peasants and artisans (Hoffman, 1986, 1994).

To apportion the tax, the total sum of the taille was divided among the regional financial districts or généralités, numbering four in the fourteenth century

\footnotetext{
${ }^{5}$ If a noble worked his land with servants, he was exempt, but if tenants were sharecroppers, the tenant's share was taxable.
} 
and growing by the acquisition of provinces and sub-division to over 25 by the late seventeenth century. The tax officials or receveurs-généraux in each généralité divided the tax obligations among the élections in the généralité, which were supervised by élus. Each élection divided its portion among the parishes. Within the parish, the parishioners assessed and collected their parish tailles. Each unit was collectively responsible for the total contribution. The structure allowed for the variations in taxation and incentives to enforce collection and monitor avoidance. Parishioners named four to eight tax collectors who were paid a commission of 2.5 to 5 percent to assess and collect taxes. They sent the money to the receveur of the élection who paid some local expenditures. About 90 percent of the revenue was forward to the receveurs-généraux who made payments assigned by the king, passing on a fraction of collections to the central treasury. These tax officials enjoyed the substantial benefit of the use of tax funds until they were obliged to remit them. Thus, they were able to provide short-term credits to the king. Overseeing the system in the Estates de Languedoil, the Cour des Aides sat in judgment on tax cases and the Cour de Comptes audited the accounts of tax officials (Collins, 1995).

In the sixteenth century the taille was augumented by additional levies-the crue, the grande crue, and the taillon---for the military, postal service, dike and levee repairs and roads and bridges. These usually took the form of surtaxes. While the taille itself was only levied on the Estates de Languedoil that had originally consented to the tax, these later additions, collectively called the tailles or the tailles et crues $y$ joint, were paid by the whole kingdom. The newer provinces also had their own local direct taxes. To administer these taxes, the newer provinces had their own receveurs-généraux, Cour de Aides and Cour de Comptes but no élus (Collins, 1988). Regional control of taxation remained strongest in the pays d'Etats that had representative Estates in contrast to the pays d'elections of the North and Center. ${ }^{6}$ The tailles were leading source of royal income. In the early 1520s, Francis I had a regular income of 8 to 10 million livres, of which approximately 5 million was obtained from these direct taxes. $^{7}$

There were three main forms of indirect taxes in ancien régime France: the salt tax or gabelle, the sales tax or aides, and the transit fees or traites. The Estates General voted the salt and sales taxes in the 1360s, and the traites evolved from the king's overlordship rights. Except for some salt producing areas, the sale of salt was monopolized in most of France. In the pays de grandes gabelles of the north, the king had salt warehouses and each household had to purchase a minimum quantity of salt. In the south-the pays de petites gabelles, taxes were levied on salt upon leaving the region of production and was traded freely upon arrival. The regional variation in taxation induced smuggling. The government responded by forming a large military force to police the

\footnotetext{
${ }^{6}$ In 1600, the pays d'Etats were Brittany, Burgundy, Languedoc, Provence, Dauphiné and the Southwest. By the early seventeenth century Dauphiné and the Southwest lost their estates.

${ }^{7}$ The clergy's décime yielded 1.1 million livres, the aides 825,000 and the gabelles 460,000 livres.
} 
gabelles. The sales taxes were levied on selected goods, notably wine. There were taxes on imports and exports (douanes), but there were also transit fees levied on goods moving from one province or regions. The numerous taxes on traded goods encouraged considerable smuggling to avoid what often constituted punitive taxes. This system had some economic logic, attempting to keep collection costs low and maximize revenue. For example, Brittany was a major salt producer and paid no salt tax as monopoly sale would have been very difficult. Wine had to be imported to the province and Brittany paid high wine taxes. On the other hand, the province of Burgundy, which produced wine but no salt, paid low wine taxes and high sale taxes (Collins, 1988).

While most direct taxes were managed by royal officials, most indirect taxes were collected by tax farmers. The choice of tax collection methods by the Crown reflected its ability to manage the "principal-agent" problem inherent in tax collection (White, 1997). Tax yields varied from year to year with economic fluctuations. Furthermore, revenues might be reduced if tax collectors were not properly motivated. The monarchy had three basic choices of contract, each offering a different incentive: (1) establish a government tax bureaucracy where tax collectors were paid a fixed wage for delivery of all revenue from a tax to the Crown, (2) create a tax farm where the tax collectors paid "rent" of a fixed sum to the government for the right to collect a tax and keep the revenue, and (3) create a revenue-sharing tax farm where the government would lease the right to collect a tax to tax collectors for a share of the revenue. Some of the factors affecting the choice of contractual form would have included the technology of tax collection, the ability of the government to monitor the tax collectors, and the degree of risk aversion exhibited by the government and its tax collectors. If the task of collecting taxes is well known and collection can be costlessly monitored, a fixed wage is an efficient incentive to motivate employees. By absorbing the risk, it will also maximize the revenue it receives. As most of the process of assessment and collection of direct taxes was assigned to the localities, the Crown assigned fixed wage officials, régisseurs, to manage the system, creating a régie. However, lacking the techniques and ability to monitor tax collectors and averse to the risk of fluctuating tax revenues from indirect taxes, the Crown most often used either form or a combination of the two types of tax farms to collect indirect taxes, accepting a lower yield to avoid risk and the monitoring problem.

In the beginning, most tax farms were individual farms, limited to small areas whose boundaries rarely coincided with other fiscal divisions. Leases were for one year and continuity of management was difficult. In the fourteenth and fifteenth century, the monarchy had competitive bidding to award leases, in the hope of driving up lease prices. The growing need for increased resources in the sixteenth century moved the Crown to seek larger consolidated tax farms, fermes-générales, operating on a regional basis. The new fermes-générales consolidated each type of tax, but even these mergers did not cover the entire kingdom. The drive to consolidate tax farms was slow and halting, with many retreats in the face of political instability and financial crises.

Venality of office was a distinctive feature of French government that included the tax officials. In the thirteenth century, the Crown found that it could sell the 
right to handle royal finances, justice and other aspects of government to officials. Depending on the office, an official benefited from management of royal monies, fees from litigants, an annual payment or gage, exemptions from taxes and social distinction. Secure tenure for life in an office was conferred in 1467. Besides death, resignation or forfeiture, the king retained the right to suppress offices (Doyle, 1996). When in 1604, Henry IV established the paulette, he made property rights to transfer an office secure by an annual payment of one-sixtieth of the official value of office. ${ }^{8}$ The king also fixed the official value of their offices and their salary or gages (Collins, 1995). Growing from 4,000 to 5,000 officers in 1515 to 15,000 a century later, this venal system produced a large vested interest in the preservation of the fiscal system.

At the apex of the tax system was the central treasury created in 1523 by Francis I. This treasury was created to reduce the dominance of the receveursgénéraux who previously had controlled tax collection. They had collected, borrowed, and disbursed funds with little oversight from the Crown, often at considerable individual profit. Centralizing the flow of funds, all receipts had to be delivered to the treasury after payment of the costs of collection and any assigned expenses, which later included debt payments. Disbursement of funds required written orders from the treasury. However, the bureaucracy of the central administration remained modest. The regional fiscal officers continued to enjoy considerable autonomy, even though they were subject to some monitoring. Overseeing the system was a superintendent of finances, a controller general and several intendants of finance.

\section{Attempts to Reform the Tax System}

In the sixteenth, seventeenth, and eighteenth centuries, the tax system created in the Middle Ages came under pressure to deliver more revenue to finance state and empire building. Successive kings attempted to increase revenue by: (1) the centralization of tax collections, (2) the reduction of tax avoidance and evasion, and (3) the increase of tax rates. However, these reforms were often partly or wholly thwarted. Tax officials did not willingly concede their profitable operations to kings and ministers seeking to raise revenues. The Crown's dependence on borrowing from these officials further limited its will to pursue reform projects. Efforts to raise revenue by cutting exemptions and raising assessments were fiercely opposed by elites and regions that benefited. Finally, the absence of representative institutions raised high political barriers to changing the structure of taxation or tax rates. Three rough periods in the evolution of the fiscal structure of the ancien régime can be discerned: (1) The mid-sixteenth to mid-seventeenth century, (2) The era of Louis XIV, and (3) The eighteenth century.

\footnotetext{
${ }^{8}$ Before the paulette, if the office holder died within forty days of transferring his office, it reverted to the king.
} 


\section{4a. Frustrated Reforms of the Sixteenth and Seventeenth Centuries}

In the late sixteenth century, Henry III (1574-1589) embarked on a series of reforms of tax administration to raise revenue for his struggles with the Huguenots, the great nobles and the provincial Estates. His overall objective was to centralize and standardize the tax system, bringing more of the kingdom under more direct royal control. In 1581, he combined the export and import duties into one farm and created a single gabelle for the North, and began centralizing the aides. This enlargement of the tax farms helped the king by improving the tax liens that secured loans from international bankers. Extending the reach of royal taxation, Henry III established new généralités and élections in areas where direct royal control had been absent or weak, eliminating, for example, the control of taxes by the Estates of Normandy.

These changes were often compromised by the exigencies of war that limited or rolled back reforms. More troubling for the long run was the sale of royal offices and the consequent growth of tax privileges, whittling away the tax base. The number of noble families rose sharply over time. The 283 percent increase between 1463 and 1666 took many potential tax payers off the rolls (Gelabert, 1995). Gaining tax exemptions from the taille and aides on wine produced on their own estates, nobles, royal officers and wealthy merchants gained a competitive advantage and purchased large quantities of agrarian land between 1550 and 1730 (Hoffman, 1986). As more productive activities escaped the fisc, revenue growth was further limited.

In spite of these difficulties, Henri III's efforts appear to have been reasonably successful. Between the 1560s and the 1580s nominal royal tax receipts trebeled. Real tax revenues climbed over 50 percent, shown by the index of total tax receipts in Figure 1. This growth was the product of a rise in the average tax burden, as the index of per capita tax receipts rose by an equivalent amount. The civil war that brought Henry IV (1589-1610) to the throne caused royal tax revenues to plummet in the 1590s. The new king sought to strengthen the Crown and centralize power in the royal councils. The last ten years of his reign brought economic recovery and a regeneration of tax revenues. Following his predecessor, Henry IV combined tax farms into larger units and reduced direct taxes, specifying more effective collection rules in the parishes.

Although troubled by revolts of nobles (1614-1617), an internal war with Protestants (1621-1629), peasant and urban revolts (1635-43), and France's entry into the Thirty Years War in 1635, the Crown enjoyed a rise in tax revenue during the reign of Louis XIII (1610-1643), as seen in Figure 1. Between the 1620 s and the 1630s, nominal and real receipts more than doubled, due in large part, to a rise in tax rates. Surtaxes were added, doubling direct taxes between 1625 and 1634. The king also tried to eliminate the greater fiscal independence of the pays d'Etats, but these changes occasioned rebellions in the provinces. In 1634, to gain more control of assessment and collection of taxes, the king introduced royal officials directly responsible to him, the intendants into the généralités. The intendants were granted the key power to apportion taxes in 1642 , but rebellion forced the king to retreat on this issue. 
Figure 1

Indexes of Total and Per Capita Tax Receipts

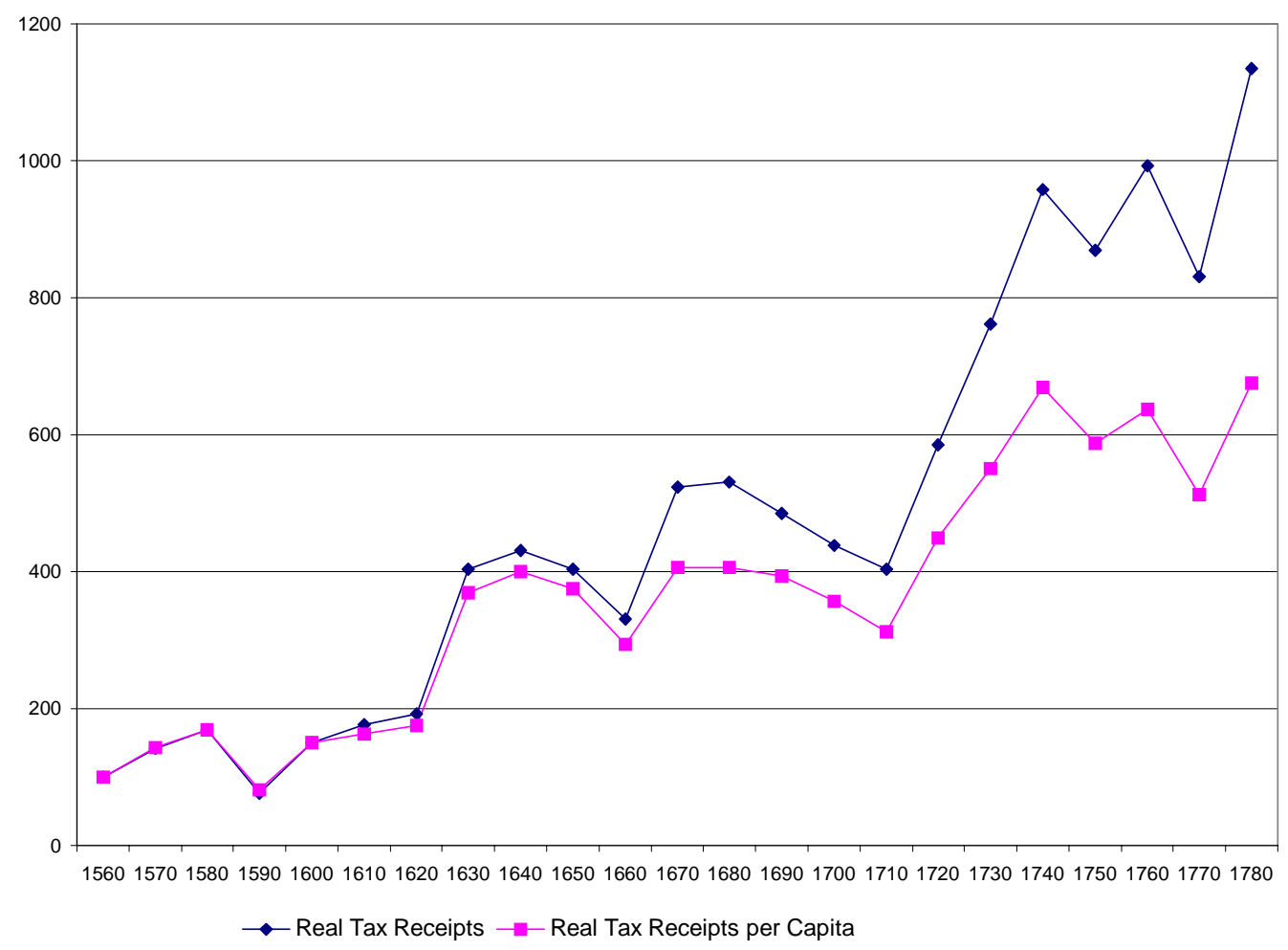

Source: Hoffman (1986, 1995).

Note: The data points represent averages for each decade of annual tax receipts converted into grain equivalents.

The period of rule by Cardinal Mazarin, beginning with the minority of Louis XIV (1643-1651) and continuing until Mazarin's death in 1661, saw France slip into internal chaos. Real tax revenues began to decline during the war (16351659) fought by France and Spain for hegemony in Europe. Throughout the conflict both sides found it nearly impossible to raise enough money to finance the war. Attempts to raise taxes resulted in revolts throughout France. When the government attempted to reduce the gages of offices and eliminate the paulette in 1648, the Parlement of Paris and the venal officers of the Crown rebelled. These events fuelled the provincial opposition to new taxes, beginning the revolt known as the Fronde. This civil war was joined the following year by the great nobility and lasted until 1653.

Overall, this period saw the beginning of the centralization of tax collections. Yet, the persistent domestic and foreign upheavals prevented more radical change. Consequently, the essential features of the tax system changed little and the privileges granted by the Crown in times of weakness became more numerous and firmly entrenched. 


\section{4b. Taxation Under Louis XIV}

When Mazarin died in 1661, Louis XIV declared himself chief minister and reorganized royal councils, beginning a major fiscal reform. Sweeping away the existing network of officials the king arrested the Superintendent of Finance, Nicholas Fouquet, and became his own chief minister. Obstructions were reduced when the parlements lost their right to registration and remonstrances in 1673 (Collins, 1995). As his head of royal finances, Louis selected Jean-Baptiste Colbert to design and oversee the reforms. For their efforts, Louis and Colbert were rewarded with not only a recovery in tax receipts from the nadir of the 1660 s, but also a higher level. Nominal receipts rose steadily from the 1670 s to the 1690s, although rising prices produced a slight decline in real revenues, as seen in Figure 1. This improvement was achieved by major changes in the organization of the tax system and improvements in its operation.

When Colbert assumed control of finances in 1661 he began a new effort to consolidate the tax farms. According to Matthews (1954), Colbert would have preferred régies to than tax farms; but increasing the king's revenue quickly was of paramount importance and for that he needed the skills of the tax farmers. Between 1663 and 1681, the finance minister slowly consolidated many of the single tax general farms into one all encompassing Fermes Générales. Colbert moved to improve the monitoring the fermiers. They were kept to a strict timing of payments and their records were scrutinized. In 1681, he unified and clarified the legal code governing tax farming. The varied and scattered farms were organized in a single institution with a clear line of accountability to the Crown. Colbert achieved the crucial goal of raising revenue, driving hard bargains with the tax farmers. In 1661, the leases signed by his predecessor Fouquet yielded 36.9 million livres. Following Colbert's reforms, the leases on the tax farms in 1683 produced 65.8 million livres for the government. This increase was an impressive achievement. Between 1661 and 1683, prices appear to have been relatively stable (Labrousse, 1970), thus the increase is roughly a real increase. If the lease prices had grown at only the (presumably higher) rate of economic growth for the eighteenth century of one percent (O'Brien and Keyder, 1978), then they would have totalled only 45.9 million livres. Instead, indirect tax revenues increased at an average annual rate of 2.7 percent.

Louis and Colbert also sought to raise more revenue from direct taxes, moving away from the exemption-riddled taille. Many influential critics attacked its inequities and promoted the principle that all subject pay according to their ability (Bonney, 1995a). In 1699, a new tax, capitation was levied on all lay people, from shepards to the Dauphin, and rates were fixed according to a table of 22 classes or occupations. While this was initially more equitable than the taille, the more influential managed eventually to secure exemptions from the capitation (Collins, 1995). When the tax was reinstated in 1701, it lacked the original progressivity. The War of the Spanish Succession drained the treasury, and a new tax, the dixième, was imposed. It was to be a temporary wartime levy of ten percent tax on all incomes. Yet, enforcement proved difficult. 
Contemporaries believed that declarations were far from accurate and were one half of actual incomes, in spite of stiff penalties (Bonney, 1995c).

To reduce the opportunities for self-enrichment by venal officials, the intendants were given greater authority to monitor them. Directly responsible to the king, the intendants watched every aspect of the collection of direct taxes from the naming of officials to assessments, demanding detailed economic data on the ability to pay of each jurisdiction.

The costly War of the Spanish Succession (1701-1713) strained the system of taxation to the limit and saw a twenty percent drop in nominal tax receipts over the previous decade with a substantial fall in real revenue, depicted in Figure 1. The lease price of the Fermes Générales fell. When receipts declined because of the war, the farmers borrowed against future receipts to make good on their obligation to the Crown. In 1697, the six-year lease had a cumulative deficit of 50.7 million livres. As taxes declined, the government borrowed heavily against future taxes. Colbert's single tax farm began to fall apart, as farmers, fearful of assuming the risk, refused the Crown's asking lease prices. Instead, many taxes were administered as régies from 1709 to 1714, with the farmers as régisseurs or commissioners accepting a fee (Matthews, 1954). Many of the tax reforms of Louis and his chief minister remained in place, even though they were compromised by more than a decade of war. Collections might be more centralized and carefully monitored, yet the essential structure of the system remained largely unchanged.

Seen alone, France's tax reforms under Louis XIV appear a major achievement; but they were quite modest in comparison with changes underway in Britain. Some aspects of the British tax system were initially similar-with the notable exceptions of French regionalism and tax exemptions. ${ }^{9}$ The hearth tax, the excise, and the customs were farmed out. Between the Restoration of 1660 and the Glorious Revolution of 1688, the Treasury Board obtained complete control of all expenditures and a comprehensive knowledge of the state's fiscal activities. Willing to take the risk of varying but growing proceeds, the Crown canceled the customs farm in 1671, the excise farm in 1683 and the hearth tax farm in $1684 .^{10}$ This development contrasts the continental fiscal systems, including those of the United Provinces and Prussia, where tax farming remained dominant and collection varied regionally. Although it took time to effect a complete transition, the British Treasury Board had control of revenue as well as expenditures. The Crown established standard procedures and customs and excise commissioners began regular inspection circuits to monitor tax collectors. The result was a highly centralized, unified national tax system (Brewer, 1988). France did not begin to move in the same direction as Britain until a century later.

\footnotetext{
${ }^{9}$ While Britain was taxed, for the most part, as a unitary state, the Celtic regions, notably Scotland, evaded taxes, frustrating officials efforts to ensure uniform payment (O'Brien, 1988).

${ }^{10}$ The hearth tax was replaced by a land tax soon after the Glorious Revolution.
} 


\section{4c. Taxation in the Eighteenth Century}

By the end of the War of the Spanish Succession, the Crown was fiscally exhausted. Nominal tax receipts recovered from their wartime low, but remained less than the level established in the 1690s. Rising prices pushed the real value of revenue below the prior decade's level. Louis XIV's death in 1715, placed the government in the hands of a regency during the minority of Louis $\mathrm{XV}$. To establish his authority against Louis XIV's will, the regent, the Duc d'Orleans restored the powers of registration and remonstrance to the parlements. Faced with huge war debt and low revenues, the Regent was willing to experiment.

In 1716, the duc de Noailles, in charge of the Crown's finances, sought to alter the character of the taille. Aware of complaints of the inequity of dividing a fixed tax among all taxpayers, he proposed a tax rate proportional to the declared income of each taxpayer. However, this project lost out to the plan of the Scot, John Law who had the regent's ear (Touzery, 1994). Although a key objective of Law's "System" was to manage the debt, he wanted control of all government finance. In 1719 Law took over the lease of the Fermes Générales followed by control of the direct taxes. His plan to completely rationalize the combined direct and indirect tax collection was aborted when his System abruptly collapsed.

Law's successors were left with the task of resurrecting the tax system. They succeeded and, in spite of all the obstacles, brought about a significant rise in real revenue. Although this increase leveled off after the middle of the century, it appears an impressive achievement in comparison with the previous two centuries. One feature that Figure 1 highlights is the greater growth of total relative to per capita tax receipts, suggesting that beyond the 1740 s revenues would have stagnated if the population had not continued to rise.

New direct taxes were raised in the eighteenth century. The dixième was used again between 1733-36 and 1741-50, during the wars of the Polish and Austrian Successions, then abolished in 1721. Philibert Orry, the comptroller general was concerned with how this tax was levied. An attempt to introduce a reformed direct tax on the basis of individual's income, faltered as each intendant set different rates on property and income, increasing rather than decreasing the tax disparities. There was strong opposition from the Cours des Aides and the élus who were threatened by the reform. This tax lost its progressive character and became a proportional supplement to the taille (Collins, 1995).

Orry's successor Machault d'Arnouville did not interfere with intendants who pursued this type of reform, but he directed his efforts to raising a new tax, the vingtième and abolished the dixième in 1749. The vingtième or "twentieth" was intended to be a five percent tax on income. It was strongly resisted by the privileged, and the edict had to be forcibly registered by a lit de justice. Although originally intended to cover all subjects, exemptions began to creep in. The clergy won exemption, and the provincial estates avoided the tax by offering lump sum payments. There was also considerable resistance to the declarations of income required for assessment (Mousnier, 1984). A second vingtième was added in 1756 for the duration of the Seven Years War plus ten years. 
In 1759, the comptroller general Silhouette planned to suspend the exemptions for the bourgeois and officers of the Crown for the duration of the war plus two years, impose a subvention générale without exemptions, and raise other tax rates. Bitter remonstrances to the king forced the minister's dismissal. Instead there was the imposition of a third vingtième, a doubling of the capitation and an increase in postal fees, excises, and customs duties (Touzery, 1994). In 1761, the Crown proposed to make the second vingtième permanent and rescind the third. Again, this innovation was tempered by exemptions granted to the privileged classes and the pays d'états. The Crown attempted to ensure a proper valuation for the tax in 1763, but opposition from the parlements forced the government to retreat; and the yield from the two vingtièmes declined (Bonney, 1995c). Every major effort at reform was thus checked or compromised from the introduction of the capitation to the employment of the vingtièmes.

The financial problems from the Seven Years' War did not disappear with the end of hostilities. There were selective defaults in 1763 and 1770. In the latter year, the parlements were suspended, giving the finance minister, the abbé Terray an opportunity to make bigger changes. He made the first vingtième permanent, and extended the second vingtieme to 1781. A variety of tax exemptions were eliminated and expenditures were reduced, bringing the budget into balance (White, 1989). Terray attempted a revision in tax assessments, but resistance from the judicial establishment hampered this effort. Thus, between 1772 and 1782 , only 4,902 parishes out of 22,508 in the pays d'élections had their rolls verified (Bonney, 1995c).

In its efforts to reform the tax system, the Crown waged a long struggle to reduce the influence of the parlements. In 1756, the two chambers of the Parlement de Paris were reduced to one. The Parlement de Pau was remodelled in 1764 and the following year, the Parlement de Rennes was reorganized. Following the political coup in 1770, an overhaul of the legal system was engineered, abolishing four parlements, remodelling the remainder, and eliminating many venal offices (Doyle, 1996). Yet, this major political reform was reversed when Louis XVI arrived on the throne in 1774. Seeking good will, the new king recalled and re-empowered the parlements.

Operating under these renewed constraints, Louis XVI's finance minister, Jacques Necker managed the financing of the American War for Independence from 1776 to 1781 with considerable success and controversy. He proposed provincial assemblies to establish more representation and suppressed many venal offices. In 1777, Necker promulgated a decree to guarantee regular reassessment of lands subject to the vingtièmes. The Parlement de Paris responded with a remonstrance that regular reassessment was the equivalent of raising permanent taxes (Stone, 1981). Necker's successor, Jean-François Joly de Fleury ended reform of the financial administration, although he gained a third vingtième for the duration of the war plus three years. When the monarchy's finances after the war continued to deteriorate, the minister Charles-Alexandre de Calonne, proposed a subvention territoriale, a tax in kind on all landed classes with no exemptions, organizing an Assembly of Notables in 1787 to circumvent the obstruction of the Parlement de Paris. The road to revolution began when 
these reforms were rejected by the hand-picked Assembly. The obstinate Parlement de Paris blocked any new taxation and proclaimed that only an Estates General could approve of new taxes. The Crown finally conceded defeat and called for a meeting of the Estates General in 1789, which had not met since 1614.

The reign of Louis $\mathrm{XVI}$, like many of his forefathers saw a see-saw of reform, producing little change in the character of direct taxation. Similarly, indirect taxation was not substantially reformed, but slow improvements---like those in direct taxation---helped to drive up the yield from taxes. In the aftermath of the collapse of Law's system, the Crown attempted to revive the Fermes Générales. The tax farmers offered a very low lease price of 40 million livres, which was rejected by the government. In its place it set up a régie in 1721, paying the former farmers salaries and bonuses. The farmers apparently turned a huge profit as the Crown was unable adequately monitor of its agents. Desiring to return to the reliability of the Fermes Générales, Louis XV's chief minister, Cardinal Fleury re-established the institution in 1726, with an annual price of 80 million livres (Mathews, 1954).

After 1726, the form and structure of the Fermes Générales stabilized. In the eleven lease contracts signed between 1726 and 1786, the lease price gradually rose from 80 to 144 million livres. Although some of this increase in revenue may be attributed to economic growth, tax rates were increased. In 1705, a surtax of 10 percent was added, and this was doubled in 1715 . In 1760, 5 percent was added, followed by another 5 percent on the gabelles and the entry taxes to Paris in 1763. This surtax was spread to all taxes in 1771 and 10 percent was added. Finally in 1781, another 10 percent was imposed and the rate made universal. Thus, between 1705 and 1781, the surtax rose from 10 to 50 percent (Matthews, 1954).

Over the course of the eighteenth century, the government began to move the farm away from a pure tax farm, intervening in such a way as there was a slow but perceptible shift towards a government takeover, even though it never materialized. The government was more willing to accept risk and improved its ability to monitor the farmers, gaining the potential for higher revenues (White, 1997). By 1776, the farm was required to seek the finance minister's permission for all important decisions. In 1778, the minister Necker began to install Crown officials within the offices of the Fermes to audit its operations, thus improving the king's capacity to monitor. The 1774 Lease required some sharing with the government of the profits. The 1780 Lease was more demanding, setting a minimum price of 122.9 million livres. If revenues exceeded 126 million, the profits would be shared evenly between the farmers' syndicate and the Crown. Confident it was moving the right direction, the Crown placed the aides and the domaines in a régie in 1780 and the traites into a régie in 1783. Yet after 1783, the movement towards a salaried corps of tax collectors halted. The failure to continue in these changes reflected the successful opposition of the entrenched interests. If the government been able to switch entirely to a régie and obtain 
most of the profits from the leases, one estimate (White, 1997) suggests that the Crown could have gained another 10 million livres of revenue. ${ }^{11}$

A comparison of the results of France's partial tax reforms in the eighteenth century with those in Great Britain is informative. While real total French revenues rose, they failed to keep pace with the growth of British revenues. Mathias and O'Brien (1976) find that indirect taxes were the engine that filled the coffers of the British king. For the whole of the eighteenth century, France seems to have increased direct and direct taxes at about the same rate, keeping the proportion of their contribution to the French fisc roughly equal. At the beginning of the century, British government finance rested firmly on indirect taxation, with direct taxes, representing approximately one quarter of tax receipts. On the eve of the Revolutionary and Napoleonic wars, this had fallen to 20 percent, thanks to the growth in receipts from indirect taxes. ${ }^{12}$ Looking more closely, customs duties provided on average about a quarter of all revenue. The principal source of Britain's rich revenues were the excises and stamp taxes levied on domestic production and services. Standing at about 35 percent of all revenue, these taxes contributed over half of the tax revenue by mid-century (O'Brien, 1988). The British Exchequer successfully identified and taxed new goods and services, which the French Crown could barely consider given the parliamentary opposition.

The striking feature of the French tax system from its foundation in the later middle ages to the end of the ancien régime is continuity. Reforming ministers and kings managed to centralize tax collections, unify the tax farms and improve monitoring. Yet, vested interests prevented the elimination of the labyrinth of privileges and regional variation, changes in the basis of taxation, or a significant increase in the level. This inflexibility made the deficit finance even more critical.

\section{Deficit Finance}

Financing frequent warfare was the central financial problem of the French monarchy. War helped form the nation states of Europe and it challenged them to efficiently marshal their resources. From the sixteenth to the eighteenth century, deficits were primarily financed by debt rather than money; and France adhered to a specie standard, with one brief bout of paper money inflation in the early eighteenth century. By adopting a specie standard, France followed the best contemporary practice and avoided the distortions of inflationary finance. However, like her instruments of taxation, France failed to modernize her instruments of borrowing. Britain had developed an efficient system of debt finance by the eighteenth century (Brewer, 1989). The consols, a simply-priced and marketable homogenous long-term security, were the principal instrument of

\footnotetext{
${ }^{11}$ At this time, the Crown's deficit stood at approximately 100 million livres.

12 The reintroduction of the income tax in 1799 to meet the exceptional demand for revenue increased direct taxation's share of total receipts to over 30 percent in the early nineteenth century (O'Brien, 1988).
} 
debt finance. The transparency of the budget and debt policies made it clear to creditors that the debt was fully funded by future taxes. In the short-term, a variety of unfunded debt instruments were employed with the Bank of England's discount operations, assisting with the management of this debt. The short-term debt was rolled over into consols and a sinking fund used to retire the long-term debt with the peacetime budget surpluses.

In contrast, France had many innovations but could not fully escape the origins of its system of debt finance. Even by the mid-eighteenth century, France's long term debt consisted of numerous heterogeneous individual issues that were complexly priced and often difficult to transfer. Furthermore, much of the Crown's borrowing, especially its short-term borrowing, rested heavily on the venal royal officials. The notes of the receveurs-généraux and the fermiersgénéraux provided much of its short-term credit. The Crown also pressured the privileged groups, like the regional Estates and the clergy to provide loans; and it continued to rely on the sale of offices, particularly in crisis times. The characteristics of the debt and the added risk of default put a premium on French securities that raised the cost of deficit finance and lessened the optimality of French macroeconomic policy.

\section{5a. Deficit Finance and the Monetary System}

Under a nineteenth classical gold or bimetallic standard, the price of specie was defined in terms of the currency and the price was fixed. The government abjured from any manipulation of the coinage, promising to keep the mint price of specie fixed through the purchase and sale of the specie in unlimited quantities. The mints convert bullion brought by the public into coin and sold coins freely to the public allowing free export or conversion into bullion. Mints charged a fee in the form of mint charges to mint coin from bullion. The mint charges less the cost of production (brassage) produced seigniorage for the Crown. Britain was the first country, in 1694, to strictly abide by the rules of this standard (Bordo and Kydland, 1995). Before the nineteenth century, the French Crown and other states deviated from this prescription, debasing the coinage to gain higher seigniorage. Debasement could be achieved by lowering the fineness of coins, increasing the number of coins struck from a fixed weight of specie, or by increasing coins' face value

Debasement of the coinage was a frequent in fourteenth and early fifteenth century France. The Crown engaged in five major debasements: 13181329, 1337-1343, 1346-1360, 1418-1423, and 1426-1429. Miskimin (1984) claims that debasement was an ineffective policy for generating revenue, undone by a rational public. However, the repeated use of the policy suggests that the Crown was successful in obtaining revenue from an inflation tax (Bordo, 1986). Examining the years 1418-1423, Sussman (1993) found that the Crown dramatically raised the seigniorage rate and gained real revenues, even exceeding tax revenues. Like other rapid inflations, the adjustment of inflationary expectations eventually undermined this debasement policy. Nevertheless, this 
switch to inflationary finance was a rational response because the collection costs of taxes had soared with war and the invasion of French territory.

While these early debasements were driven by a need to generate substantial revenues for the government, debasements in the sixteenth and seventeenth centuries had a mixed character. Glassman and Redish (1988) and Sargent and Velde (1998) have argued that debasement in these centuries was more often used to solve the technical problems of coinage than as a purely revenue generating instrument. Coins of the period suffered heavily from wear and tear and illegal clipping. When these coins continued to circulate at their legal value, full-weight coins became undervalued and the latter circulated at a premium or were driven out of circulation. The solution was to raise the mint price to meet the market price. A similar problem occurred in bimetallism when the legal tender values of gold and silver coins departed from their relative market values, causing one metal to become undervalued. Debasement of the coinage was the technique selected by governments to correct for the undervaluation with the objective of promoting the efficient operation of the monetary system. Many of the claims that debasements were for revenue (Bonney, 1981) appear to be adjustments to induce coin to flow back into France.

Under Colbert, there appears to have been no debasement of the currency. ${ }^{13}$ After his death, finance ministers declared enhancements of the price of coin in $1689,1693,1701,1704$, and 1709. Although there are no recent studies of these changes, they were during periods of serious wartime financial difficulties. In 1701, complaints were heard that the 8 percent reduction in the value of coins (the reduction was 10 percent in 1689) had eliminated the interest profits on short-term loans (Collins, 1995). It is not clear that this was different than earlier policy, as the changes in coin values were no larger than the reductions in the first half of the century. However, what may have caused more unrest after 1701 was the issue of coin certificates when the mint could not keep up with the pace of reminting. Initially, the quantity issued was small, 6.7 million livres in 1703. When the Crown realized that it could engage in a form of fractional reserve banking, it created a caisse d'emprunts or loan treasury in 1704, issuing notes bearing 6 to 10 percent interest; and the coin certificates began to carry interest. Reaching a total of 180 million livres in circulation in 1706, the certificates' market value fell by to 60 to 70 percent of face value by 1707 (Bonney, 1995c). A new finance minister, Desmarets created the caisse Legendre that pooled the resources of the twelve receveurs-généraux who issued interest-bearing notes collateralized by taxes. By the end of the War of the Spanish Succession, the caisse had issued 400 million livres, providing the government with substantial short-term credit (Collins, 1995).

John Law's efforts to reform the debt and tax system, described more fully below, included a bank of issue, the Banque Royale. The expansion of banknotes to support securities prices produced an inflation; the collapse of the

13 In 1674, Colbert created the caisse d'emprunts, a type of bank. Individuals exchanged existing annuities for interest bearing certificates at the caisse that were convertible to cash, subject to notice. (Korner, 1995). 
"System" left a strong distaste for any paper money or attempt to manipulate the value of the livre. This experiment helped to bind the Crown more firmly to a specie standard. In 1726, France returned to the bimetallic standard at a bimetallic ratio of 14.5. In this respect, France "caught up" to best British monetary practice of strict adherence to a specie standard. Investors in French debt were guaranteed that their returns would not be reduced by a depreciation of the currency. This new French regime prevailed until the Revolution, with only a change in the bimetallic ratio to 15.5 in 1785 to adjust to higher world price of gold. The abandonment of seigniorage reflects the rise in tax revenues, the product of reforms that lowered collection costs. Eschewing an inflation tax, reduced distortions and improved the optimality of policy

The failure of Law's Banque Royale also engendered a strong political aversion to chartering any institution with the tainted name of a bank. Consequently, the finances of the French state were hampered by the absence of a banking institution, capable of providing the state with short-term liquidity to manage its debt, especially in wartime. In the next five decades, banking was almost exclusively private discount banking. After years of agitation from the financial industry, the Crown created the Caisse d'Escompte in 1776, modelled on the Bank of England---nearly eighty years after this important British innovation (Bigo, 1927). The Caisse was organized as a limited liability partnership with the right to discount bills of exchange and other commercial paper at a maximum interest rate of 4 percent and issue banknotes redeemable in coin. In the absence of other chartered banks, it had a de facto monopoly. Largely owned by members of the private banking houses, the Caisse was primarily a bankers' bank, offering credit to its members.

During the American War for Independence, the Caisse assisted with war finance by providing credit to the private bankers who helped to launch state loans. The Crown sold its loans to the private bankers who resold them, while drawing on short-term credit from the Caisse d'Escompte. After the war, in 1783, when the Crown exhausted its ability to float new securities, it demanded a secret loan from the Caisse d'Escompte. When it was rumored that note issue was rising, a run on the bank began. To the government's embarrassment, it was halted when the administrators of the Caisse made their accounts public and the Crown was forced to repay its loan. Afterwards the stockholders reorganized the bank and increased its reserves to restore public confidence. As the state's problems grew worse, the new minister, Calonne coerced the bank in 1785 to provide a 70 million livre loan. Rising loans to the Crown and growing note issue forced a suspension of redemption in 1789, beginning the Revolutionary era of fiat money (Bigo, 1927).

\section{5b. The Origins of French Debt Finance}

While taxes were raised during wartime and some revenue was occasionally gained from seigniorage, most war finance was paid for by borrowing. Debt finance, which permits a tax-smoothing policy, was potentially efficient. However, in the sixteenth and seventeenth century, France found it 
nearly impossible to follow this policy as its tax revenues were rarely sufficient to cover the costs of servicing new war debts. Consequently, lenders understood that borrowing was contingent on favorable outcomes and the anticipation of default added a premium to the cost of borrowing. Instead of paying down the wartime debt with peacetime surpluses, the monarchy defaulted after most wars.

France's approach to debt financed deficit expenditure was formed in the early sixteenth century. One of the catalyzing events was the financial crisis of 1522-1523. At this time, the receveurs-généraux dominated the fiscal system. With minimal accountability, they held and managed all tax receipts and handled the disbursement of funds with the kings' private treasurer. These officials also served as the king's primary bankers, borrowing money in his name or their own. In the midst of a war with Charles V, Francis I was stung by a financial crisis. He responded by purging the receveurs and creating the central treasury to control the disbursement of funds.

The abysmal state of royal credit led to the creation of a new debt instrument, the rentes sur l'Hotel de Ville de Paris, loans collateralized by specific taxes. The king assigned a source of revenue to the Provost of the Merchants and Aldermen of Paris; in turn, the Hotel de Ville (city hall) created municipal rentes of equivalent value that were sold to the buyer. This structure provided a guarantee by a very influential group. Many merchants, aldermen and members of the Parlement bought the rentes. Thus, constituted, these loans carried a lower rate of interest than the rate demanded by financiers (Dent, 1973). Rentes were eventually issued against most tax revenues---tailles, the royal domain, aides, gabelles, and traites. When the Crown received contributions in the form of loans from the clergy and the regional Estates, they were often constituted using this system. Gradually, the rentes became an important form of borrowing by the Crown. By the end of the sixteenth century, the Crown had moved towards broader market debt. Yet, borrowing from the receveurs and fermiers provided much of the short-term credit, and the long-term debt was held by many powerful and wealthy individuals-the "bourgeois gentilshommes" including many royal officers (Collins, 1988).

Another key innovation by Francis I was the establishment of the bureau des parties casuelles (the bureau of casual parts) to collect non-recurrent income. Most of this revenue came from the sales of royal offices that offered tax exemptions and other benefits. The sale of offices became a major financial instrument, with the annual payments providing the interest on the loan, as well as an engine for generating tax privileges. Sales of offices were used intensively during times of greatest financial need, suggesting that the package of annual payments and other benefits made this the most costly form of borrowing Financial entrepreneurs, traitants or partisans, proposed the sale of offices to the government and received commissions. (Doyle, 1996).

At the same time as Francis I introduced these institutions, he executed a default accompanied by a chambre de justice. While the partial default reduced the king's outstanding debts, the concentration of the debt meant that it was aimed at the Crown's privileged creditors, many of whom appeared to or actually took advantage of their position to earn enormous profits. Beginning in the 
fourteenth century, the king would occasionally convene a special commission to uncover financial wrongdoing. A chambre typically swept through the fiscal system, netting many of the leading and well-connected financiers. The accused were heavily involved in the dual tasks of tax collection and lending to the government, either as royal officials or traitants and partisans. Usually a pamphlet campaign blamed them for profiteering at the expense of the state and the people. The chambre had the power to impose penalties, ranging from modest fines to the death penalty. Some accused fled the country while others battled the court. In most cases the sentences were never applied, and the accused would "redeem" themselves by paying a fine to the king for immunity or amnesty. (Mousnier, 1984). The chambres de justice have been described as attempts to satisfy public opinion outraged by the financiers immorality and abuses (Bosher, 1973), to free the king from control of a group of financiers (Mousnier, 1984), or a fiscal device to raise revenue and curb excesses (Collins, 1988). They appear, however, to have been a strategic instrument in the process of managing the debt in the process of default. The financial officers had profited during the hard times of war through short-term lending to the government. The Crown might be in debt to them currently, but they had already reaped substantial profits, unlike long-term lenders who had been offered high interest rates and had the prospect of high future returns. A partial default on the longer term debt shifted the risk of the bad outcome ex post to the longer term lenders. A default might not strike the short term lenders as hard. Consequently, their profits were adjusted ex post by a chambre de justice, imposing fines and lowering the returns to lending because of the bad state.

Like the creditors of the Crown, historians have found it difficult to discover the exact state of the Crown's deficit and debt, especially for the sixteenth and seventeenth centuries. The failure to adopt double-entry book keeping and the multiple and partial accounts renders it a nearly impossible task. Guéry (1978) provides a table of revenues, expenses, and deficits; but his misreading of the accounts yields an improbable result with over a century of large deficits. Bonney (1981) offers a more careful reading of the documents that highlights the gaps and omissions, emphasizing the impossibility of producing any credible series. Nevertheless, the impression he provides reveals a pattern of wartime spending funded by borrowing, followed by default and a return to some semblance of fiscal balance.

As the figures for the state of the budget and the debt are in such dispute for the sixteenth and seventeenth centuries, Table 4 is offered instead of dubious numbers. This table shows the major wars and revolts from the sixteenth to the eighteenth centuries, the defaults on the debt and the chambres de justice. The first two defaults shown and the accompanying chambres de justice were part of the financial house keeping that Henry IV and his minister, the Duke of Sully, carried out at the end of the wars of religion. In 1596-1598, Sully estimated the debt at 296 million livres. Of this total outstanding, creditors, including the Swiss Cantons, German princes, England and the Netherlands, who held 147 million livres were forced to accept a partial reduction in their claims (Collins, 1988). Further repudiations in 1602 , with the chambres de justice, helped to make the 
Crown solvent again. By 1611, Sully had a projected surplus of 4.6 million livres with total expenses of 20.4 million (Bonney, 1981).

Table 4

War, Defaults and the Chambres de Justice

\begin{tabular}{l|cll}
\hline \multicolumn{1}{c|}{ War } & Years & \multicolumn{1}{c}{ Year of Default } & \multicolumn{1}{c}{$\begin{array}{c}\text { Chambres de } \\
\text { Justice }\end{array}$} \\
\hline Last War of Religion & $1585-1598$ & 1598 & 1597 \\
War with Savoy & $1600-1601$ & 1602 & $1601-2, \quad 1605-7$, \\
& & & 1607 \\
Revolts by the Nobility & $1614-1617$ & & 1624 \\
Civil War with Protestants & $1621-1629$ & & 1635 \\
Mantuan War & $1629-1630$ & 1634 & $1643,1645,1648$ \\
France enters the Thirty Years War & $1635-1648$ & 1648 & \\
The Fronde & $1648-1653$ & 1652 & $1656-7,1661-5$ \\
War with Spain & $1650-1659$ & $1661-1667$ & \\
Flemish War & $1667-1668$ & & \\
Dutch War & $1672-1678$ & & \\
War of the League of Augsburg & $1688-1697$ & & \\
War of the Spanish Succession & $1702-1713$ & $1716,1720,1726$ & 1716 \\
War of the Polish Succession & $1733-1738$ & & \\
War of the Austrian Succession & $1740-1748$ & & \\
Seven Years War & $1756-1763$ & 1759 & \\
American War for Independence & $1776-1783$ & 1770 & \\
\hline
\end{tabular}

Note: Sources differ on the dates of the Chambres de Justice.

Sources: G. Dujarric, Précis Chronologique d'Histoire de France (1981), Bonney (1973), Mousnier (1984), Collins (1988), and Collins (1995).

The assassination of Henry IV in 1610 began France's long descent into civil war, the revolt of the Fronde, entrance into the Thirty Years War and finally War with Spain. Once again, the budgetary figures for the years between 1610 and 1660 are notoriously difficult to interpret, but the chronic state of royal finances is clear. The Crown borrowed heavily and frequently failed to meet its obligations---accepting three major defaults, 1634, 1648 and 1652 with the attendant chambres de justice. Often the monarchy borrowed at exorbitant rates. For example, in 1634, rentes paying 7.14 percent were sold for a yield of 33 percent or higher; and frequently payments were in arrears (Dent, 1973). At the end of the War with Spain, the Crown was paying over 25 percent interest on loans arranged by financiers who collected large fees. In the 1620s and 1630s, the king also borrowed directly from his tax officers through the droits aliénés. These were rights to collect surtaxes on direct and indirect taxes, priced at ten times the annual value of the right or droit (Collins, 1988). In 1634, the king defaulted by converting the surtaxes into annuities and reducing the effective interest payments on the capital from 10 percent to 4.16 percent. Desperate for revenue, the sales of royal offices soared. The number of offices was increased 
by separating functions, creating and abolishing districts, and alternating years for holding offices. The sale of offices helped to spawn a large bureaucracy with a vested interest in protecting its privileges, including tax exemptions. Income from the bureau de parties casuelles that had averaged about 10 percent of total ordinary royal income in the first decade of the century rose to 50 percent in the 1620 s and 1630s (Bonney, 1981). The gages became a heavy financial burden on the Crown. When Cardinal Richelieu surveyed the king's finances in 1639, he discovered that annual payments to officials had exceeded income from sales. ${ }^{14}$

A financial clean-up began in 1661 with Louis XIV's personal government and the nomination of Colbert as comptroller general in 1662. A chambre de justice swept away Nicolas Fouquet, the previous minister and his financial network. Colbert estimated that the venal offices represented a capital of 419 million livres from which the king received a tax of 2 million and paid out gages of 8.3 million, and he began a suppression of offices. According to Colbert, 20,000 offices were suppressed, but the costs of the Dutch War (1672-78) induced the king to sell new offices to raise revenue (Doyle, 1996). The interest payments on the rentes, many of which had been sold with high yields were also reduced. The end result of Colbert's work was an essentially solvent Crown at the beginning of the next round of wars. Colbert's accomplishment, even after the Dutch War, is seen in Table 5, where in 1683, the debt payment to revenue ratio was 18.5 percent. The Crown was able now to raise revenue without resort to bankruptcy or a chambre de justice until 1716. Mousnier (1980) attributes this change to the reforms of Colbert that gave the government greater control over the tax system, presumably limiting the ability of the financiers to earn higher profits.

\section{Table 5 \\ The Burden of the Debt}

\begin{tabular}{c|ccc}
\hline & $\begin{array}{c}\text { Tax Revenues } \\
\text { (Livres millions) }\end{array}$ & $\begin{array}{c}\text { Debt Payments } \\
\text { (Livres millions) }\end{array}$ & $\begin{array}{c}\text { Debt to Revenue } \\
\text { (Percent) }\end{array}$ \\
\hline 1683 & 119 & 22 & 18.5 \\
1699 & 145 & 48 & 33.1 \\
1706 & 118 & 63 & 53.4 \\
1713 & 131 & 90 & 68.7 \\
1724 & 197 & 65 & 33.0 \\
1740 & 211 & 57 & 27.0 \\
1753 & 257 & 72 & 28.0 \\
1764 & 322 & 124 & 38.5 \\
1775 & 377 & 155 & 41.1 \\
1788 & 472 & 292 & 61.9 \\
\hline
\end{tabular}

Sources: Collins (1995), p. 163 gives debt payments for 1683-1713, and the tax revenue (decade averages) is from Hoffman (1986), Table 2. Marion (1914), pp. 120-1 provides the data for 1724 and Weir (1989), Table 2 for 1740-1788.

\footnotetext{
${ }^{14}$ By comparison, while English kings had used the sale of offices and honors, this practice remained relatively modest because of the smaller involvement of Britain in the protracted military struggles on the continent (Brewer, 1988).
} 
Beginning with the Flemish War and culminating with the War of the Spanish Succession, the military ventures of Louis XIV became more expensive. At the beginning, the Crown benefited from the steady rise in real tax revenues seen in Figure 1; but the mounting costs and steady, if not declining real revenues, made wartime borrowing increasingly expensive. On the eve of the Spanish War of Succession, the debt service to revenue ratio is already high at 33 percent. Although measurement of the Crown's debt is a hazardous enterprise, it is clear that it rose considerably. Table 5 shows that debt payments grew much more rapidly than tax revenue, more than trebling in nominal terms between 1683 and 1713 .

In this setting, a broadening of the market with new financial instruments was an important innovation. In 1689, the Crown issued the first tontines. The tontines pooled an issue of rentes viagères or life annuities, where the annual payments accrued to the survivors. Both the tontines and life annuities tapped a larger pool of savings for public finance. In their first use, the tontines drew in ten thousand subscribers who provided 6.5 million livres. To a considerable extent, these new instruments replaced the more costly borrowing by the sale of venal offices. In the War of the League of Augsburg, Louis XIV raised four times as much by the sale of rentes (Doyle, 1996).

Although the War of the Spanish Succession secured the throne of Spain for Louis XIV's claimant, it was a disastrously expensive endeavor. It is generally thought that the debt contracted during war amounted to about one billion livres (Collins, 1995). There is a wide range of estimates of the total debt at the end of the war. Bonney (1995b) believes that the interest-bearing public debt was 1,739 million livres in 1715. Clamageran (1886) prefers 1,936 million, while Riley (1986) sees a debt of 2,600 million livres in 1714. Usually excluded in these calculations is the value of the venal offices, which Doyle (1996) estimates in 1721 to have been between 700 and 800 million livres. In spite of these uncertain figures, the burden of the debt clearly rose to an unsustainable level. Interest payments climbed from 33 percent of tax revenues in 1699 to 69 percent at the war's end.

At the death of Louis XIV, the regent was unable to meet interest payments. A chambre de justice and partial default were begun in 1716. The short term debt was reduced, interest rates were cut and the chambre de justice set fines of 219 million livres (Marion, 1914). Yet, these traditional drastic measures did not solve the Crown's financial dilemma. The regent turned to John Law, the Scots adventurer and financial advisor. In 1716, Law founded the Banque Générale, a joint stock bank of issue. Seeking a vehicle for debt management, Law established the Compagnie d'Occident in 1717 with monopoly rights to the exploitation of Louisiana. The public was invited to exchange depreciated debt for shares in the new company, which was presumably profitable because of its monopoly. Accepting the stock below face value, the company agreed to receive lower interest payments from the Crown. The public was pleased to obtain fixed interest irredeemable debt for tradeable variable yield securities and the Crown was eager to have its debt service cut. Adding more privileges, including trading companies, the tax farms and minting rights, Law's "System" gathered 
momentum with the issue of the non-convertible notes and loans by the renamed Banque Royale (Neal, 1990). Inflation induced by this banking expansion led Law to attempt to control stock prices, interest rates, and the specie value of the livre. The incompatibility of these goals produced a spectacular collapse of the "System" in 1720. The prices of shares and banknotes plunged. The value of the debt was not much reduced, standing at about 2.2 billion livres (Marion, 1914); but by 1724 interest payments were cut back to where they were in the early stages of the war, as seen in Table 5 . The clean up of Law's debacle took another six years and another default in 1726 until the state's debt service was lowered to a manageable level.

\section{5c. Debt Finance in the Eighteenth Century}

Two important consequences of Law's failed experiment were the abandonment of paper money and strict adherence to a specie standard. Adherence to a bimetallic standard constrained France's macroeconomic choices; and policy focused on taxation and management of the debt, setting up a less distortionary macroeconomic policy regime. Fortunately, there are better statistics for the remainder of the ancien régime in the eighteenth century that allow a closer analysis of the Crown's policies.

The fiscal balance of the French Crown can be viewed in Figure 2. The data underlying this chart do not form consistent series and should be taken to show the general magnitudes rather than the precise fiscal state of the government. ${ }^{15}$ Figure 2 shows that after John Law's debacle and the subsequent defaults, the budget was roughly in balance. During the War of the Polish Succession (1733-1735), there was a budget deficit, but it disappeared afterwards. The War of the Austrian Succession (1741-1748) quickly sent the budget back into the red. In the absence of reliable data, what happened in the succeeding eight years of peace is unclear. Although in two years of peace 1749 and 1750, there was still a fairly large deficit. Yet, it seems clear that the Crown had managed two important wars without resorting to a default. Compared to earlier and later wars, these two required somewhat lower spending. The Polish War cost approximately 62 million livres or 21 million per year, which was 10 percent of ordinary revenues. The Austrian war was more expensive, perhaps 500 million livres, with an annual cost of approximately 25 percent of ordinary revenues. ${ }^{16}$ Part of the fiscal success may also be attributed to the rise in real tax revenue, seen in Figure 1. The monarchy's borrowing capacity is evidenced in its pricing of life annuities that were age graded, at rates that were close to

\footnotetext{
${ }^{15}$ The deficits for the years 1773-1788 were obtained from White (1989, Tables 1 and 3$)$. For the period 1727-1768, Riley (1987, Tables 1 and 2) provided the deficit information. To measure the size of the deficit, Riley's figures for credit items (borrowing) were subtracted from total revenue. For the years 1756-1762, there was little information on total revenues and expenditures. Instead, credit items in the affaires extraordinaires were used as a proxy for borrowing. Actual borrowing may have been lower if there were reimbursements, or it may have been higher if there was borrowing recorded elsewhere. However, credit items appear to be the bulk of the borrowing. To measure the real deficit, Labrousse's price index (1970, Vol. II, p. 387) was used.

${ }^{16}$ Calculated from Riley (1982).
} 
actuarial fairness (Velde and Weir, 1992). The French Crown appears to have moved closer to the strategy of tax smoothing in these thirty years than anytime before or afterwards. Nevertheless, the French debt was still a contingent claim, with a real possibility of default. As seen in Figure 3, which reports the yields on consols or near-consol securities, the French Crown had to pay a substantial risk premium compared to Britain. ${ }^{17}$ France took steps to improve its financial reputation. Debt service on long term debt appears to have gradually declined from 67 million livres in 1722 to 60 million in 1734, 51 million in 1739 and 49 million in 1740 (Riley, 1986). After the Austrian War, the minister Machault established a sinking fund, the Caisse de Amortissement, in 1749. The proceeds of the new vingtième were assigned to this fund for the purpose of reducing the debt by repurchases, but it never became fully operational, as the tax revenues were diverted to paying the interest on the debt.

Figure 2

French Government Deficits

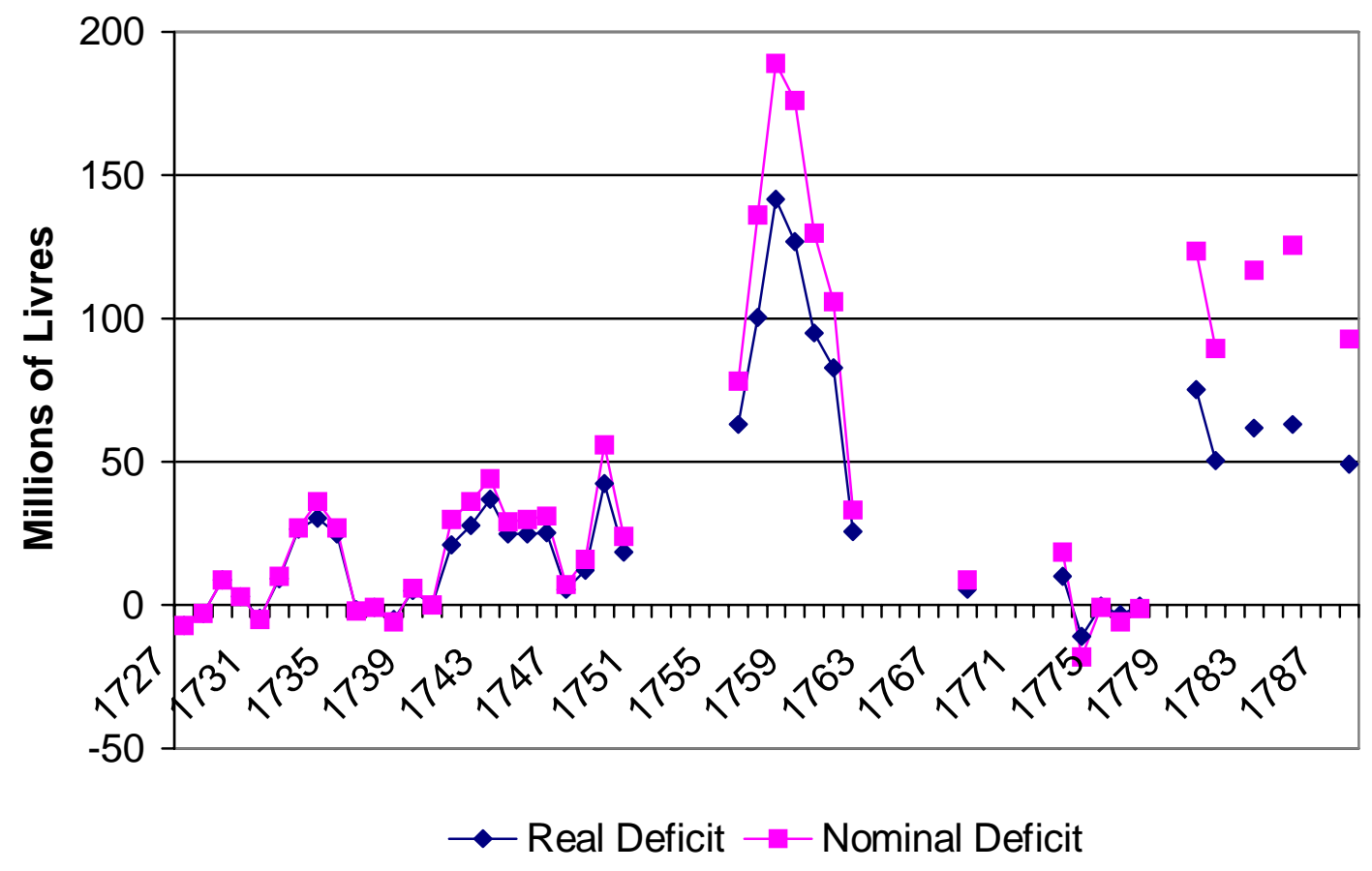

The Seven Years War (1756-1763) put an enormous strain on government finance. The unexpected duration and intensity of the war required much greater expenditures that the two previous wars. Riley (1986) estimated the cost of the war at 1,325 million livres or about 190 million livres per year. Furthermore, the rapid increase in real tax revenues, shown in Figure 1, appears to have leveled off, and the annual cost was averaged over 70 percent of ordinary tax revenues. Only thirty percent of the cost was financed by tax

${ }^{17}$ The source for France is Velde and Weir (1992) and Britain Homer and Sylla (1996). 
increases. Thus, the deficit seen in Figure 2 was much larger during the Wars of the Polish and Austrian Successions. Yields increased on the government securities in Figure 3, as expected in the tax-smoothing model (Barro, 1987) to reallocate resources; but the increase in France was greater than in Britain, suggesting greater borrowing requirements and perhaps a greater risk of default.

Figure 3

Yields on British and French Securities

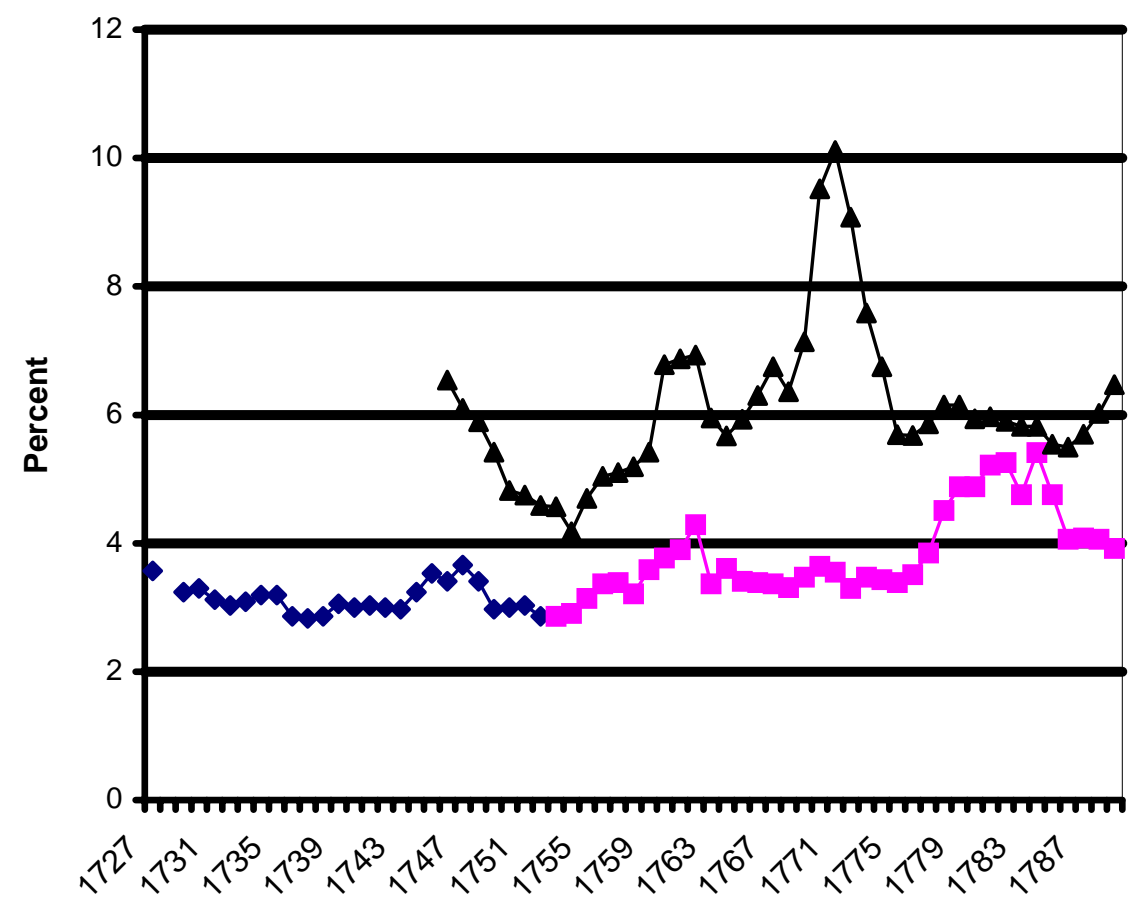

$\multimap$ British 3\% Annuities

$\rightarrow$ British 3\% Consols

$\rightarrow$ French October Loan

One indication of increased financial stress was that in 1757, the Crown abandoned age graded pricing of life annuities in favor of more costly and more attractive flat rate pricing (Velde and Weir, 1992).

Financial innovation continued to broaden the market for government debt. During the War of the Polish Succession, twenty-five thousand people contributed 26 million livres in the sales of tontines; and the same number 30 million during the War of the Austrian Succession. Almost fifty thousand contributors to one tontine produced 47 million livres for the Seven Years War. Issued in times of peak demands for war finance, the internal rates of return offered by both assets were attractive (Weir, 1989). In 1758, the government allowed the purchase of a life annuity on two lives, rather than one, with 
payments at a lower rates (Shakespeare, 1986). Apparently alarmed by the costs, the Crown banned the issue of any tontines in the future in 1763. The multiple-life rentes viagères now proved popular, and in 1770, enterprising financiers hit upon the Genevan formula where life annuities were constituted on twenty young women who had survived small pox and lived in the healthy city of Geneva. The annuities were pooled and subscribers could receive a high return while reducing risk. This form of rentes became a major source of financing during the American War.

The unexpected financial stress of the Seven Years War led the Crown to conduct a selective, partial default in 1759. Long term loans were unaffected, but the short term notes issued by the venal officers of the Crown were forcibly converted into longer term debt and reimbursements of the debt were suspended. ${ }^{18}$ This type of default was an "excusable" default, shifting the cost to a relatively select group that had earned high interest on credit to the Crown. Yet, it is important to note that the more broadly held debt made a chambre de justice less useful as an instrument of redistribution and made it more politically difficult for a default.

In the postwar years, the Crown struggled to correct its fiscal imbalance, without much success. Before the Seven Years War, Riley (1986) estimated the debt in 1753 at approximately 1,200 million livres, requiring an annual service of 85 million livres. By 1764, he calculated the debt to be approximately 2,324 million livres---back to the level of 1714---with a debt service of 196 million livres. In 1764, the government sought to revive the Caisse d'Amortissement (a sinking fund) to retire the debt, supplying it with new funds, and established a Caisse d'Arrérages to make interest payments on the rentes viagères, tontines, rentes perpétuelles with the income from the two vingtièmes. However, this manuevering did not permit any substantial reduction in the debt. Finally in 1770 , the Crown was forced into a partial default. As in 1759, payments on short-term debt issued by the receveurs and fermiers were suspended and forcibly converted into long-term debt. But, the default went further. Pensions were cut and the tontines were forcibly converted to life annuities, lowering the future payments to the owners. The yields on other loans were lowered to 4 percent or less. ${ }^{19}$ The result of this partial default was that the debt service was lowered to approximately 154 million livres per year or about 40 percent of annual revenues (Vuhrer, 1886), still a very high charge on the budget. This default was broader and less selective, causing yields to soar. The partial default may have been "excusable," given the unexpectedly higher cost of the war, and it did not exclude the Crown from the market; but it seems to have stiffened resistance to any future defaults. ${ }^{20}$

The fiscal reforms (White, 1989) kept the Crown in rough balance once again until the outbreak of the American War (1778-1783). After this last ancien

\footnotetext{
${ }^{18}$ In 1763, the Crown also reduced the reimbursable capital value of some loans sold during the war (Velde and Weir, 1992).

${ }^{19}$ In addition, the finance minister converted the tax on dividends, earmarked to pay for debt retirement, into a 10 percent tax on all interest payments.

${ }^{20}$ Considering the high yields paid on debt Riley (1986) considers it a "pre-paid repudiation.
} 
régime war, the Crown was never again able to come close to balancing its budget. The cost of the war has been estimated at 1,066 million livres, or slightly less than the Seven Years War (Harris, 1976). Almost all of this war---997 million livres---was paid for with borrowing. Given the last default, the potential creditors need reassurance that default was not an inevitable outcome. The finance minister, Jacques Necker apparently persuaded the public with his bold attempt to follow a tax-smoothing strategy (Bordo and White, 1991 and 1994), but he was unable to secure the tax increases this required. Thus constrained, he sought to reduce the ordinary, non-war expenditures of the Crown to fund the additional debt. Whether this strategy would have worked is the source of considerable controversy, but the failure to pursue tax reforms and manage the debt well subsequently proved fatal to the monarchy. By one estimate (Vuhrer, 1886), the service on the funded debt alone had reached 208 million livres, with a large unfunded debt outstanding. By the late 1780s, the Crown was in the position of borrowing to cover its debt service, beginning an explosive growth of the debt (White 1989). Politically, default was inexcusable and the Crown had to call for a new Estates-General, thereby setting the stage for the Revolution.

Like the tax system, the system of borrowing was never fully reformed. The critical needs of war financing led successive kings and finance ministers to continue their reliance on a system of privileged lenders that included the tax officials and the venal office holders. Their importance was somewhat diminished over time, and new forms of debt were issued that drew on the national and international financial markets. Nevertheless, the monarchy was unable to completely depend on the open market. The inability to generate sufficient tax revenue and its frequent defaults made it a risky borrower. Rather than incur even higher cost loans, it retreated to the old system. Instead of the more efficient tax-smoothing policy adopted by the British of paying down the last war's debt with peacetime surpluses, the French failed to raise taxes and built up the debt from one war to the next until default was necessary. High cost, inefficient public finance was thereby guaranteed.

\section{Conclusion}

While France's failure to hold on to its American empire, left it little legacy for the new world, its absence provides an important example of unsuccessful public finance. There were political constraints hampering reform and the development of a modern fiscal system. Privilege shaped French society and privilege shaped the fiscal system, with vested interests it created blocking reform efforts. Varied and diverse tax privileges limited the growth of tax revenues and spawned a hostility to their unfairness. Privilege created a venal class of government officials that controlled the tax system and dominated short term borrowing. When the demands of war built up an unsustainable level of debt, partial defaults and chambres de justice punished these officials but never removed them. Even after the reforms of the eighteenth century, France remained shackled by macroeconomic institutions and policies that failed to provide the requisite revenue for the retention of New World colonies. 


\section{Bibliography}

Barro, Robert J., "Government spending, interest rates, prices and budget deficits in the United Kingdom," Journal of Monetary Economics 20 (September 1987), pp. 221-248.

Barro, Robert J., "The Neoclassical Approach to Fiscal Policy," in Robert J. Barro, ed., Modern Business Cycle Theory (Cambridge, 1989), pp. 236-264.

Bigo, Robert, La Caisse d'Escompte (Paris, 1927).

Bonney, Richard, The King's Debts: Financ and Politics in France, 1589-1661 (Oxford: Clarendon Press, 1981).

Bonney, Richard, "Early Modern Theories of State Finance," in in Economic Systems and State Finance (Oxford: Clarendon Press, 1995), pp. 163-230.

Bonney, Richard, "The Eighteenth Century. II. The Struggle for Great Power Status and the End of the Old Fiscal Regime," in Economic Systems and State Finance (Oxford: Clarendon Press, 1995), pp. 315-392.

Bonney, Richard, "Revenues," in Economic Systems and State Finance (Oxford: Clarendon Press, 1995), pp. 423-506.

Bordo, Michael D., "Money, deflation, and seigniorage in the fifteenth century: A review essay," Journal of Monetary Economics 18 (November 1986), pp. 337-346.

Bordo, Michael D. and Finn E. Kydland, "The Gold Standard As a Rule: An Essay in Exploration," Explorations in Economic History 32 (October 1995), pp. 423-464.

Bordo, Michael D. and Eugene N. White, "Tale of Two Currencies: British and French Finance During the Napoleonic Wars," Journal of Economic History (June 1991).

Bordo, Michael D. and Eugene N. White, "British and French finance during the Napoleonic Wars," in Michael Bordo and Forrest Capie, eds., Monetary Regimes in Transition (Cambridge: Cambridge University Press, 1994), 241-273.

Bordo, Michael D. and Carlos Vègh, "What If Alexander Hamilton Had Been Argentinean? A Comparison of the Early Monetary Experiences of Argentina and the United States." (mimeo, November 1998).

Bosher, J.F., "Chambres de justice in the French monarchy," in J.F. Bosher, ed., French Government and Society, 1500-1850, Essays in Memory of Alfred Cobban (London: The Athlone Press, 1973).

Bouchary, Jean, Marché des changes de Paris a la fin du XVIle siècle 1778-1800 (Paris: Paul Hartmann: 1937).

Brewer, John, Sinews of Power: War, Money and the English State, 1688-1783 (Cambridge: Harvard University Press, 1988).

Bulow, Jeremy and Kenneth Rogoff, "Sovereign Debt: Is to Forgive to Forget?" American Economic Review 79 (March 1989), pp. 43-50.

Bulow, Jeremy and Kenneth Rogoff, "A Constant Recontracting Model of Sovereign Debt," Journal of Political Economy 97 (February 1989), pp. 155-178. 
Butel, Paul and François Crouzet, "Empire and Economic Growth: The Case of $18^{\text {th }}$ Century France," Revista de Historia Economica XVI (Invierno 1998), pp. 177-193.

Clamageran, J.-J., Histoire de l'Impot en France (Paris: Librarie de Guillaumin et Cie., 1876).

Collins, James B., Fiscal Limits of Absolutism: Direct Taxation in Early Seventeenth Century France (Berkeley: University of California, 1988).

Collins, James B., The State in Early Modern France (Cambridge: Cambridge University Press, 1995).

Dent, Julian, Crisis in Finance: Crown, Financiers and Society in Seventeenth Century France (Newton Abbot: David and Charles, 1973).

Doyle, William, The Parlement of Bordeaux (New York: St. Martin's Press, 1974).

Doyle, William, Venality: The Sale of Offices in Eighteenth Century France (Oxford: Clarendon Press, 1996).

Dujarric, G., Précis Chronologique d'Histoire de France (Paris: Albin Michel, 1981).

Fritschy, Wantje, "Taxation in Britain, France and the Netherlands in the eighteenth century," in Economic and Social History of the Netherlands Vol. II (Amsterdam: NDHA, 1990), pp. 57-80.

Gelabert, Juan, "The Fiscal Burden," in in Richard Bonney, Economic Systems and State Finance (Oxford: Clarendon Press, 1995), pp. 539-576.

Glassman, Debra and Angela Redish, "Currency Depreciation in Early Modern England and France," Explorations in Economic History 25 (January 1988), pp. 75-97.

Grossman, Herschel I. and John B. Van Huyck, "Sovereign Debt as a Contingent Claim: Excusable Default, Repudiation, and Reputation," American Economic Review 78 (December 1988) ,pp. 1088-1097.

Guéry, A., "Les finances de la monarchie française sous l'ancien régime," Annales E.S.C. XXXIII (1978), pp. 216-239.

Harris, Robert D., "French Finances and the American War, 1777-1783," Journal of Modern History 48 (June 1976).

Hoffman, Philip T., "Taxes and Agrarian Life in Early Modern France: Land Sales, 1550-1730," Journal of Economic History XLVI, No. 1 (March 1986), pp. 37-55.

Hoffman, Philip T., "Early Modern France, 1450-1700," in Philip T. Hoffman and Kathryn Norberg, Fiscal Crises, Liberty, and Representative Government, 1450-1789 (Stanford: Stanford University Press, 1994), pp. 226-252.

Homer, Sidney, and Richard Sylla, A History of Interest Rates (New Brunswick: Rutgers University Press, 1996). $3^{\text {rd }}$ Edition.

Korner, Martin, "Public Credit," Economic Systems and State Finance (Oxford: Clarendon Press, 1995), pp. 507-538.

Labrousse, Ernest, Histoire Economique et Sociale de la France Vol. II (Paris: Presses Universitaires de France, 1970). 
Lévy-Leboyer, Maurice and Francois Bourguignon, The French Economy in the Nineteenth Century (Cambridge: Cambridge University Press, 1985).

Mankiw, N. Gregory, "The Optimal Collection of Seigniorage: Theory and Evidence," Journal of Monetary Economics 20 (1987), pp. 327-341.

McCusker, John J., Money and Exchange in Europe and America, 1600-1775: A Handbook (Chapel Hill: University of North Carolina Press, 1978).

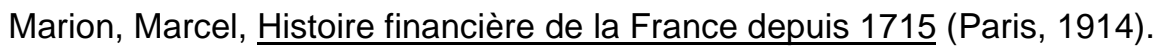

Mathias, Peter and Patrick O'Brien, "Taxation in Britain and France, 1715-1810. A Comparison of the Social and Economic Incidence of Taxes Collected for the Central Governments," Journal of European Economic History 5 (1976), pp. 601-649.

Matthews, George T., The Royal General Farms in Eighteenth Century France (Columbia University Press, New York, 1958).

Miskimin, Harry A., Money and Power in Fifteenth Century France (New Haven: Yale University Press, 1984).

Mousnier, Roland E., The Institutions of France under the Absolute Monarchy, 1598-1789 Vol. II, (Chicago: University of Chicago Press, 1980).

Neal, Larry, The Rise of Financial Capitalism, International Capital Markets in the Age of Reason (Cambridge: Cambridge University Press, 1990).

North, Douglass and Barry Weingast, "Constitutions and commitment: evolution of institutions governing public choice," Journal of Economic History (December 1989), 803-832.

O'Brien, Patrick, and Caglar Keyder, Economic Growth in Britain and France 1780-1914 (London: Allen and Unwin, 1978).

O'Brien, Patrick, "The Political Economy of British Taxation, 1660-1815," Economic History Review XLI (February 1988), pp. 1-32.

Ormrod, W. W., "The West European Monarchies in the Later Middle Ages," in Richard Bonney, Economic Systems and State Finance (Oxford: Clarendon Press, 1995). 123-160.

Price, Jacob, France and the Chesapeake (Ann, Arbor).

Riley, James C., The Seven Years War and the Old Regime in France: The Economic and Financial Toll (Princeton: Princeton University Press, 1986).

Riley, James C., "French Finances, 1727-1768," 59 Journal of Modern History (June 1987), pp. 209-243.

Sargent, Thomas J. and François R. Velde, "The Evolution of Small Change," (mimeo, December 1997).

Shakespeare, Howard J., France: The Royal Loans, 1689-1789 (Shrewsbury: Squirrel Publications, 1986).

Stone, Bailey, The Parlement of Paris, 1774-1789 (Chapel Hill: University of North Carolina Press, 1981). 
Sussman, Nathan, "Debasements, Royal Revenues, and Inflation in France During the Hundred Years' War, 1415-1422," Journal of Economic History 53 (March 1993), pp. 44-70.

Touzery, Mireille, L'invention de l'impot sur le revenu: La taille tarifée 1715-1789 (Paris: Comité pour l'Histoire Economique et Financière de la France, 1994).

Velde, François R. and David R. Weir, "The Financial Market and Government Debt Policy in France, 1746-1793," Journal of Economic History 52 (March 1992), pp. 1-40.

Vuhrer, A., Histoire de la Dette Publique en France (Paris: Gerger-Levrault et Cie., 1886).

Weir, David R., "Tontines, Public Finance, and Revolution in France and England, 1688-1789," Journal of Economic History XLIX (March 1989), pp., 95-124.

White, Eugene N., "Was There a Solution to the Financial Crisis of the Ancien R・ gime," Journal of Economic History (September 1989).

White, Eugene N., "The French Revolution and the Politics of Government Finance, 1770-1815," Journal of Economic History LV, 2(June 1995), 227-255.

White, Eugene N. "L'éfficacité de l'affermage de l'impôt: la Ferme Generale au XVIIle siecle," L'administration des finances sous 1• Ancien Régime (Paris: Comité pour l'histoire économique et financière de la France, 1997), 103-120. 